TI 2015-023/VIII

Tinbergen Institute Discussion Paper

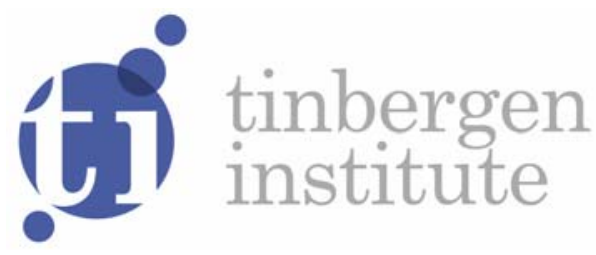

\title{
Historic Amenities and Housing Externalities: Evidence from The Netherlands
}

Hans R.A. Koster

Jan Rouwendal

Faculty of Economics and Business Administration, VU University Amsterdam, and Tinbergen Institute, the Netherlands. 
Tinbergen Institute is the graduate school and research institute in economics of Erasmus University Rotterdam, the University of Amsterdam and VU University Amsterdam.

More TI discussion papers can be downloaded at http://www.tinbergen.nl

Tinbergen Institute has two locations:

Tinbergen Institute Amsterdam

Gustav Mahlerplein 117

1082 MS Amsterdam

The Netherlands

Tel.: +31(0)205251600

Tinbergen Institute Rotterdam

Burg. Oudlaan 50

3062 PA Rotterdam

The Netherlands

Tel.: +31(0)10 4088900

Fax: $+31(0) 104089031$

Duisenberg school of finance is a collaboration of the Dutch financial sector and universities, with the ambition to support innovative research and offer top quality academic education in core areas of finance.

DSF research papers can be downloaded at: http://www.dsf.nl/

Duisenberg school of finance

Gustav Mahlerplein 117

1082 MS Amsterdam

The Netherlands

Tel.: +31(0)20 5258579 


\title{
Historic Amenities and Housing Externalities: Evidence from The Netherlands*
}

\author{
By HANS R.A. $\operatorname{KOSTER}^{a}$ AND JAN ROUWENDAL ${ }^{b}$
}

This version: 11 February 2015.

\begin{abstract}
SUMMARY - It has been argued that the growth of cities is increasingly determined by the presence of amenities. We study the economic effects of large scale subsidised investments in historic amenities, by looking at their impact on house prices. We aim to distinguish between the direct and indirect effect of investments. The latter implies a change in the behaviour of neighbours via changes in the level of maintenance of the house. We use a large nationwide dataset with housing transactions from 1985-2011 and data on investments in cultural heritage. To control for the fact that these investments are non-randomly distributed over space we use repeat sales. Furthermore, we construct an instrument based on yearly fluctuations in the size of national subsidy programmes to maintain cultural heritage. We show that a one million euro per square kilometre increase in investments in cultural heritage leads to a price increase of 1.5-3.0 percent of non-targeted buildings. We do not find evidence that the maintenance state of properties that are not eligible for subsidies are improved, suggesting that any price effect due to investments in cultural heritage is a direct effect of investments.

JEL-code - R30, R33

Keywords - cultural heritage; historic amenities; housing externalities; hedonic pricing.
\end{abstract}

\section{Introduction}

It has been argued that urban amenities are a crucial determinant of the urban economic growth of many contemporary cities (Brueckner et al., 1999; Glaeser et al., 2001). Roback (1982) was one of the first to argue that differences in amenities, or the quality of life, may cause substantial wage and house price differences between cities. Urban amenities may not only be crucial for the growth of cities, but may also impact the urban spatial structure and are a critical factor in location choices of households within the city.

\footnotetext{
* This work has benefited from a VENI research grant from the Netherlands Organisation for Scientific Research. We thank NVM and the Department for Cultural Heritage (RCE), and Remco Laverman in particular, for providing data and Donald Kreiken for providing research assistance. Gabriel Ahlfeldt, Sevrin Waights, Floris Lazrak and the participants of the Tinbergen Institute workshop on the Economics of Cultural Heritage are thanked for useful comments on previous versions of this paper. ${ }^{a}$ Corresponding author. Department of Spatial Economics, VU University, De Boelelaan 11051081 HV Amsterdam, e-mail: h.koster@vu.nl.

${ }^{b}$ Department of Spatial Economics, VU University, De Boelelaan 11051081 HV Amsterdam, e-mail: j.rouwendal@vu.nl.
} 
An important example of an urban amenity is the presence of cultural heritage. Historic amenities are thought to contribute to an attractive living environment and may attract shops, restaurants and other modern urban amenities. European cities, in contrast to US cities, generally offer historic amenities to tourists and to its residents,.

Historic amenities will most likely imply a positive external effect on the local economy: benefits are not only enjoyed by the users, but also by visiting tourists and residents living close to the building. Furthermore, historic amenities may attract high-skilled high-income workers that may generate knowledge spillovers (Brueckner et al., 1999; Koster et al., 2014; Falck et al., 2015; Van Duijn and Rouwendal, 2015). However, costs of maintaining and preserving historic buildings are not necessarily shared among those who enjoy the benefits. ${ }^{1}$ The presence of an external effect therefore provides a good reason for local and national governments to protect cultural heritage. Many governments indeed have taken measures to preserve cultural heritage, by designating historic districts and by introducing subsidies for renovation and maintenance (Ahlfeldt et al., 2014). For instance, in the Netherlands these subsidies have been in place since the 1970s when many listed buildings were in a poor condition. The subsidy programme has been successful in the sense that most ( 90 percent) of the national listed buildings are now considered to be in a good condition.

In this study we aim to measure the external effects of these - often substantial investments in historic amenities on the housing market. There are arguably two external effects of investments in cultural heritage on surrounding properties. First, there is a direct positive effect of the investment on the prices of surrounding houses because a higher quality of historic amenities raises the overall amenity level in the neighbourhood. Second, households may adjust the quality of their house through private investments in maintenance and outward appearance. This will lead to subsequent changes in prices when housing quality is also enjoyed by neighbouring households (the indirect effect). RossiHansberg et al. (2010) predict that the provision of housing quality by individual households will decrease when governments provide funding to improve the neighbourhood, which implies a negative indirect effect on house prices. We show that the latter outcome crucially depends on (arbitrary) functional form assumptions of the utility function. Hence, it is an empirical question whether the level of housing quality provided by households changes due to investments in the neighbourhood.

To distinguish between the direct and indirect external effect of cultural heritage, we not only test the impact of investments in cultural heritage on house prices, but also on the maintenance level. We use a dataset on investments in individual listed objects since 1985 and a house price transaction dataset that covers about 70 percent of the transactions in the Netherlands since 1985.

\footnotetext{
${ }^{1}$ For example, a medieval church in the centre of a square may help to make this an attractive location for cafés and restaurants, but the costs of keeping the exterior of the church in good condition will not be paid by the owners of these enterprises. The visitors of religious services in the church may also be unable or unwilling to do so, and their willingness to pay for the cultural heritage aspect may be smaller than that of the visitors of the surrounding cafés and restaurants.
} 
To measure the causal impact of changes in the local amenity level due to investments, one faces several difficulties with respect to endogeneity. More specifically, historic amenities are often clustered on attractive locations (e.g. city centres), which may lead to a spurious correlation between historic amenities and house prices. This implies that identifying external effects caused by historic amenities require an exogenous source of variation in the amenity level of a given location. To control for all unobserved time-invariant housing and neighbourhood attributes, we use repeat sales and temporal variation in investments in cultural heritage. This should strongly reduce the problem of omitted variable bias. Still, the investments may be correlated with unobserved price trends. For example, the investments in city centres may be correlated with a renewed interest in city living. To make it more plausible that we identify a causal external effect of investments in cultural heritage on house prices and the maintenance level, we use exogenous variation in spending in national subsidy programmes in the spirit of Bartik (1991) and Moretti (2010), among others. Based on the stock of listed buildings in 1985 and the total subsidies in cultural heritage per year, we predict the expected investments in cultural heritage for each neighbourhood. One may argue that unobserved trends may be correlated to the stock of listed buildings in 1985, so we extensively control for interactions of the number of listed buildings in 1985 and time. This implies that we assume that unobserved trends that are related to the number of listed buildings in 1985 are reasonably smooth over time. We subject our conclusions to a wide range of robustness checks. In the sensitivity analysis we for example use an alternative 'quasi-experimental' approach based on the designation of historic districts.

It should be noted that this is not the first study that examines the house price effects of historic amenities. ${ }^{2}$ However, most of these studies are of a limited geographical and temporal scope, do not investigate the effect on housing quality, and are cross-sectional. To the best of our knowledge, this paper is the first that uses temporal variation in the quality of cultural heritage to identify the effects on house prices. It is also the first paper that aims to distinguish between direct and indirect effects of investments in cultural heritage.

The results show a profound impact of cultural heritage investments on house prices, but we find no evidence that the maintenance level of non-eligible properties are affected by investments in cultural heritage. This suggests that the main price effect of the investments is a direct effect. We show that a million euro investment per square kilometre (about 1.2 standard deviations) leads to an increase in house prices of 1.5 percent. A counterfactual analysis suggests that the external benefits of investments in cultural heritage exceed the costs.

The paper proceeds as follows. In the next section we discuss the theoretical implications of place-based investments. Section III discusses the cultural heritage policies in the Netherlands. In Section IV, we elaborate on the empirical estimation strategy and data.

2 See for example Asabere et al. (1994), Schaeffer and Millerick (1991), Leichenko et al. (2001), Navrud and Ready (2003), Coulson and Lahr (2005), Ahlfeldt and Maennig (2010), and Koster et al. (2014). 
Section V presents and discusses the results. We also report a counterfactual analysis to gain understanding on the quantitative implications of our results. In Section VI, we subject our results to an extensive sensitivity analysis, including an alternative identification strategy. Section VII concludes.

\section{Cultural heritage, housing services and prices}

A. The model

To structure our thoughts and motivate the empirical work, we formalise the hypothesised impacts of investments in the built environment in a model. We consider a neighbourhood with houses and other buildings. All houses are assumed to be identical in their physical characteristics, including lot size, but may differ in the state of maintenance, quality of the garden, et cetera. The inhabitants of the house determine the values of these attributes, which has been referred to as housing quality in the previous section. To formalise this, we treat housing quality as a single homogeneous commodity, available in arbitrary quantities at a given unit price and refer to it as housing services (see Rossi-Hansberg et al., 2010). Housing services thus refer to the quality of a house as far as it can be affected by the inhabitant through maintenance, improvements in outward appearance, the garden et cetera, while keeping the (other) physical characteristics unchanged. The level of housing services is determined by the inhabitant of a house, but it is observed and appreciated by neighbours, and may have an impact on their consumption of housing services as will be discussed below. There are also other (non-residential) buildings in the neighbourhood with a given (outward) quality. Some of the other buildings are listed and (subsidised) investments in those buildings may occur that increase the quality of the exterior. This is observed by the inhabitants of the neighbourhood and affects their utility as well as - potentially - their own consumption of housing services. We are interested in the impact of such investments on the value of houses in the neighbourhood. ${ }^{3}$

The consumers who inhabit a house at location $i$ derive utility $u_{i}$ from consumption of a composite good $g_{i}$, the housing services of the house they inhabit $h_{i}$, the housing services consumed by their neighbours, indicated as $A_{i}$, and the quality of the other buildings in the neighbourhood $B_{i}$. Each household chooses the amount of housing services of their own house, as well as their consumption of the composite good. They take the housing services consumed by the other inhabitants of the neighbourhood, as well as the quality of the other buildings, as given. Formally, the utility function can be written as $u_{i}=u\left(g_{i}, h_{i}, A_{i}, B_{i}\right)$. Utility is increasing in all its arguments and the indifference curves are convex. Utility is maximised subject to the budget constraint $w-r_{i}=g_{i}+k h_{i}$, where $w$ denotes income, $r_{i}$ the rent to be paid for the house and $k$ is the cost per unit of housing services. ${ }^{4}$ The rent $r_{i}$ equilibrates

\footnotetext{
3 The setting just described differs from the actual situation that we study because some listed buildings are houses. However, we will not analyse price differences of such houses in our analysis, so to avoid inessential complication in the model, we assume here that houses are not listed.

${ }^{4}$ The unit of the composite good is chosen so that its price equals one.
} 
supply and demand in the local market and may depend on the physical characteristics of the house, which are taken as given by the inhabitants of the house. Utility maximisation subject to the budget constraint leads to a demand equation for housing services that can be written as $h_{i}=h\left(w-r_{i}, k, A_{i}, B_{i}\right)$.

We define $A_{i}$ as a weighted average of the housing services of i's neighbours and we define $B_{i}$ as a weighted average of some indicator $\bar{h}_{j}$ of the quality of other buildings in the neighbourhood:

$$
A_{i}=\int_{j} \omega_{i j} h_{j} \mathrm{~d} j, \quad B_{i}=\int_{\ell} \omega_{i \ell} \bar{h}_{\ell} \mathrm{d} \ell .
$$

The integrations refer to all houses except that inhabited by $i$ and to all other buildings at other locations, respectively, and $\omega_{i j}$ and $\omega_{i \ell}$ are non-increasing functions of distance between $i$ and house or other building at other locations $j$ and $\ell$. In most of the empirical work we specify it as a step function that is positive for short distances and zero otherwise.

In the empirical application we consider a situation in which $B_{i}$ changes as a consequence of a subsidy programme for listed buildings. The change in $B_{i}$ has an immediate impact on well-being as well as a possible effect on the demand for maintenance by households. If the latter effect occurs, $A_{i}$ will also change, which - similarly - can have an immediate impact on well-being as well as a possible effect on the demand for housing services by households.

Our model is related to Rossi-Hansberg et al. (2010), who also assume that households derive utility from the housing services consumed by neighbours. ${ }^{5}$ They assume that the housing services of one's own house and the indicator of the housing services consumed by others are perfect substitutes, which rules out the possibility that a change in $A_{i}$ or $B_{i}$ has an impact on utility that does not affect the marginal utility of housing services $h_{i}$, or has a positive impact on the demand for housing services $h_{i}$ and therefore leads to a higher $A_{i}$. One can easily imagine that people appreciate their neighbour's garden or a good state of maintenance of a nearby monument without any change in the demand for housing service for their own house. It may also be that a better condition of the houses and other buildings in the neighbourhood increases the consumption of $h_{i}$. Ioannides (2003) and Patacchini and Venanzoni (2014), for example, find substantial social interaction and peer effects on the maintenance of houses. This evidence clearly indicates the need for more general specifications of the utility function.

5 In our notation, Rossi-Hansberg et al. (2010) specify the utility function as $u\left(c_{i}, h_{i}, A_{i}, B_{i}\right)=u\left(c_{i}, h_{i}+A_{i}+B_{i}\right)$. We may treat the quality of other buildings in the same way as the housing services of other houses, i.e. as being also a perfect substitute for the housing services of the house one inhabits. Rossi-Hansberg et al. use a Cobb-Douglas specification for $u(\cdot)$. 


\section{B. Social interactions, equilibrium and investments}

In the remainder of this section we assume preferences can be described by a simple variant of the indirect utility function that Hausman (1981) showed to be consistent with a linear demand function: 6

$$
v\left(w-r_{i}, k, A_{i}, B_{i}\right)=\mathrm{e}^{-v k}\left(\frac{\tau+v(w-r)+\phi k+\chi A_{i}+\psi B_{i}}{v}+\frac{\phi}{v^{2}}\right)+\rho A_{i}+\sigma B_{i} .
$$

The first term on the right-hand side determines the demand for housing services, while the last two terms represent the direct effects of the housing services of one's neighbours and of the quality of other buildings in the neighbourhood on utility, respectively. The strength of these direct effects is indicated by the parameters $\rho$ and $\sigma$. Application of Roy's identity gives the demand function $h_{i}=\tau+v\left(w-r_{i}\right)+\phi k+\chi A_{i}+\psi B_{i}$, where the parameters $\tau, v, \phi, \chi$ and $\psi$ denote the intercept and the impact of income-minus-rent, the price of housing services, housing services consumed by neighbours and the quality of maintenance of other buildings on household $i$ 's demand for housing services, respectively. This demand function allows for positive as well as negative effects of $A_{i}$ and $B_{i}$ on housing services, as the signs of $\chi$ and $\psi$ can be negative as well as positive. To make sure that utility is increasing in $A_{i}$ and $B_{i}$ we assume that $v>0$, which tells us that the demand for housing services is normal and that $\chi / v+\rho>0, \psi / v+\sigma>0$. This utility function allows for a rich set of possible impacts of investment in cultural heritage on utility and the demand for housing services.

The dependence of the demand for housing services on the amount of housing services consumed by others implies a social interaction effect. To see this more clearly, we write the system of equations for all households in matrix notation as $\boldsymbol{h}=\tau \boldsymbol{\iota}+v(w \boldsymbol{\iota}-\boldsymbol{r})+\phi k \boldsymbol{\iota}+$ $\chi \boldsymbol{\Omega}_{A} \boldsymbol{h}+\psi \boldsymbol{\Omega}_{\boldsymbol{B}} \overline{\boldsymbol{h}}$, where we have used bold symbols to indicate vectors and matrices, $\boldsymbol{\iota}$ denotes a vector with all its elements equal to one, and $\boldsymbol{\Omega}_{\boldsymbol{A}}, \boldsymbol{\Omega}_{\boldsymbol{B}}$ are matrices with the weights $\omega_{i j}$ and $\omega_{i k}$ as elements. It then should hold that $\boldsymbol{h}=\left(\boldsymbol{I}-\chi \boldsymbol{\Omega}_{\boldsymbol{A}}\right)^{-1}\left(\tau \boldsymbol{\iota}+v(w \boldsymbol{\iota}-\boldsymbol{r})+\phi k \boldsymbol{\iota}+\psi \boldsymbol{\Omega}_{\boldsymbol{B}} \overline{\boldsymbol{h}}\right)$. This equation shows that the quality of other buildings has a direct impact on maintenance when $\psi \neq 0$. In addition to this direct impact there is an indirect impact via social interactions if $\chi \neq 0$.

To study the equilibrium on the housing market we start considering the conventional setup with renters and absentee landlords and then consider the situation with owneroccupiers, which is more relevant for our empirical work. ${ }^{7}$ Rents in the neighbourhood adjust in such a way that utility is equal to a given level $\bar{v}$ for all households. The indirect utility

\footnotetext{
${ }^{6}$ The choice of this functional form is - of course - to some extent arbitrary and motivated by the convenience of a linear demand equation. We could also have formulated variants of Cobb-Douglas, CES, translog or AID preferences that allow for direct effects as well as effects on the demand equation that can be of either sign. An analytical expression for the direct utility function associated with (2) does not seem to exist. However, the conditions under which a function of income and prices can be considered as the indirect utility function associated with preferences that satisfy the standard properties are well-known (see e.g. Deaton and Muellbauer, 1980).

7 Note that we assume that the rent is determined by the housing characteristics that are given, whereas the housing services are determined by the household through decisions on maintenance of the house and perhaps the garden. The tenant has to pay these expenses.
} 
function $v(\cdot)$ must thus reach the same value at all locations, so $v\left(w-r_{i}, k, A_{i}, B_{i}\right)=\bar{v}$. Let us evaluate the impact of an investment in the quality of some of the other buildings in the neighbourhood, $\Delta B_{i}>0$. This may lead to changes in the housing services of all houses in the neighbourhood $\Delta A_{i}$ as well as changes in rents $\Delta r_{i}$. If the reservation utility $\bar{v}$ remains unchanged, we must have $v\left(w-r_{i}-\Delta r_{i}, k, A_{i}+\Delta A_{i}, B_{i}+\Delta B_{i}\right)=\bar{v}$.

For the indirect utility function (2), the change in rent that keeps utility constant is:

$$
\Delta r_{i}=\left(\frac{\chi}{v}+\mathrm{e}^{v k} \rho\right) \Delta A_{i}+\left(\frac{\psi}{v}+\mathrm{e}^{v k} \sigma\right) \Delta B_{i} .
$$

The two expressions in brackets are positive because utility is increasing in the two neighbourhood quality indicators. Since the quality of other buildings will improve because of the investments we consider, the second term on the right-hand side is clearly positive. However, the sign of the first term is ambiguous because we allow for the possibility that inhabitants of the neighbourhood decrease the consumption of housing services. The changes in the $h_{i}$ 's that underlie the changes in $A_{i}$ can be written as $\boldsymbol{\Delta} \boldsymbol{h}=\left(\boldsymbol{I}-\chi \boldsymbol{\Omega}_{\boldsymbol{A}}\right)^{-1}\left(-v \boldsymbol{\Delta} \boldsymbol{r}+\psi \boldsymbol{\Omega}_{\boldsymbol{B}} \boldsymbol{\Delta} \overline{\boldsymbol{h}}\right)$, and $\Delta \boldsymbol{A}=\boldsymbol{\Omega}_{\boldsymbol{A}} \boldsymbol{\Delta} \boldsymbol{h}$. Using these equations, it is not difficult to solve for $\Delta r$ as a function of $\Omega_{B} \Delta \bar{h}=\Delta B .^{8}$ The change in the value of the houses is the net present value of all changes in the present and future rents that caused by the investments in other buildings.

In our application, we consider an owner-occupied market. This implies that there is no increase in rents (or user cost) that keeps utility constant. This means that the change in rent vanishes in the housing services equation, which leads to:

$$
\boldsymbol{\Delta} \boldsymbol{h}=\left(\boldsymbol{I}-\chi \boldsymbol{\Omega}_{\mathrm{A}}\right)^{-1} \psi \boldsymbol{\Omega}_{\boldsymbol{B}} \boldsymbol{\Delta} \overline{\boldsymbol{h}},
$$

Hence, the change in housing services is larger in the owner-occupied market, which may be interpreted as a positive impact of homeownership on neighbourhood quality. ${ }^{9}$ Substitution of the remainder of (4) into (3) gives:

$$
\boldsymbol{\Delta} \boldsymbol{r}=\left[\left(\frac{\chi}{v}+\mathrm{e}^{v k} \rho\right) \boldsymbol{\Omega}_{\boldsymbol{A}}\left(\boldsymbol{I}-\chi \boldsymbol{\Omega}_{\mathrm{A}}\right)^{-1} \psi+\left(\frac{\psi}{v}+\mathrm{e}^{v k} \sigma\right)\right] \Delta \boldsymbol{B} .
$$

This is the compensating variation of the impact of the investment in other buildings on the utility of the homeowners and the net present value of these compensating variations is the increase in the value of the houses in the neighbourhood. Our empirical work takes (5) as the starting point and attempts to measure the change in house prices that is caused by investments in listed buildings.

It is clear that (5) incorporates all effects of such investments: the direct effect on utility as well as indirect effects that occur via adjustments in the demand for housing services. In an attempt to shed some light on the composition of this total effect, we will also estimate an

\footnotetext{
8 The equation is cumbersome and does not offer any new insights, so we do not show it here.

${ }^{9}$ It may be argued that this is an underestimate because there may be a positive effect of the higher housing wealth of the homeowner on his demand for housing services. Note, moreover, that tenants may be more restricted in changing the level of housing services (due to restrictions imposed by the landlord) than homeowners in reaction to changes in the neighbourhood situation.
} 


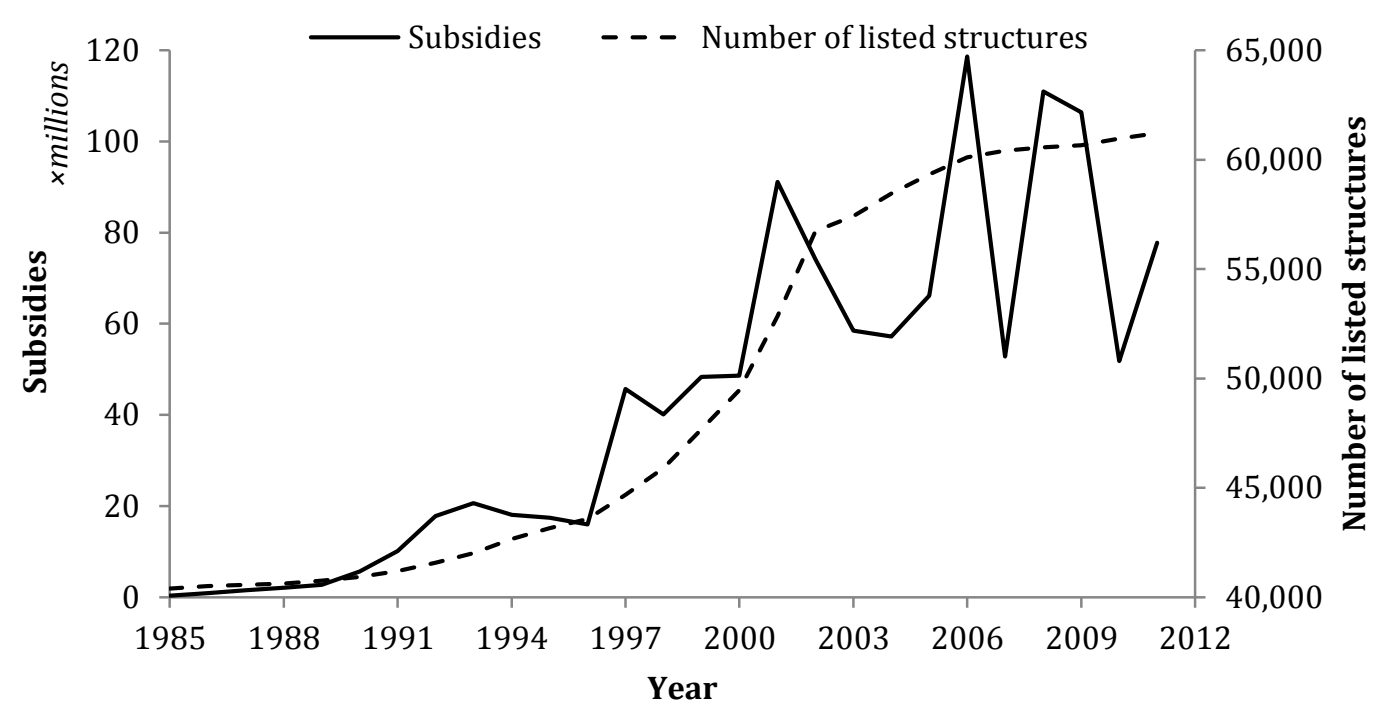

FIGURE 1 - INVESTMENTS IN CULTURAL HERITAGE OVER TIME

equation based on (4) that relates the consumption of housing services - proxied by the state of maintenance of houses as reported by the realtor - to investments in listed buildings. Estimation of this equation provides us with information about the importance of the first term in square brackets on the right-hand side of (5). For instance, if we find no impact of the investments on the state of maintenance of houses the neighbourhood, this would suggest that such investments do not invoke a direct impact on the demand for housing services $(\psi=0)$, but there may still be a sizeable direct effect on utility $(\sigma>0)$ that is reflected in house prices.

\section{Cultural heritage in the Netherlands}

Cultural heritage policies in the Netherlands aim at protection and preservation of the historic building stock. An important instrument is to list individual objects, which gives the object a special status. The procedure for listing buildings in the Netherlands started with the determination of a shortlist referring to a particular period. In the early 1960s heritage dating back to the period before 1850 was considered. In the early 1980s a shortlist for heritage from the period 1840-1940 was completed and currently the buildings of the postWorld War II period are taken into consideration.

Listed buildings face several restrictions. It is of course not allowed to demolish the object, but also (small) changes to the exterior or interior of the house (e.g. changing window frames) are often not allowed. On the positive side, one may deduct the maintenance costs from taxable income, and the listed building status may imply positive reputation effects. However, arguably the most important benefit of listing is that the building is eligible for subsidies for renovation and maintenance. 


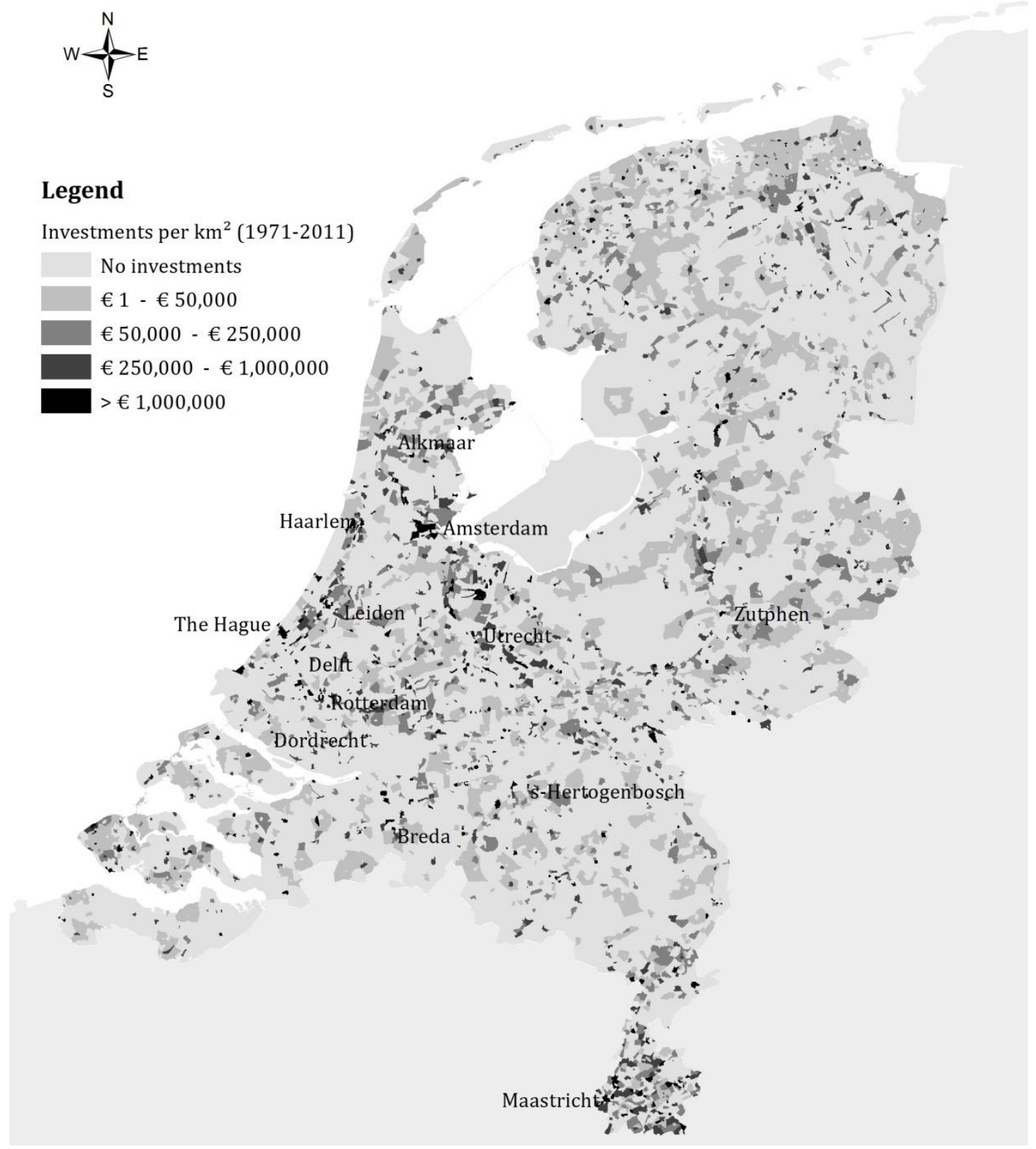

FiguRE 2 - CULTURAL HERITAGE INVESTMENTS IN THE NETHERLANDS

Subsidies on cultural heritage were introduced in the 1970s. Total public expenditures on renovation subsidies have been more than a billion euros since then. Figure 1 reports the spending on renovation subsidies of cultural heritage in the Netherlands over time. After the 1990s, concerns were raised about the poor condition of many historic buildings, so several subsidy programmes were introduced afterwards. Public spending on cultural heritage was the highest in 2006 due to the launch of a new subsidy programme. It is observed that there is a strong correlation with the upward trend in the number of listed buildings ( $\rho=0.878$ ), 
which might indicate the increased societal awareness for cultural heritage. Note that the collective spending cannot influenced by local policy makers or house owners. Most spending occurs in general subsidy programmes, but from 2000 onwards spending is more often targeted at specific types of listed buildings. About 40 percent of the spending on cultural heritage is part of these latter type of programmes. For example, there is a programme specifically targeted at extensive renovations of large listed buildings (e.g. castles, churches), while another programme entirely focuses on historic country estates. We refer to Appendix A for more details.

Figure 2 shows that investments in cultural heritage are far from evenly spread over the country and concentrated in larger cities (Amsterdam, Utrecht, The Hague, Leiden), which have a substantial stock of listed buildings. Also, some medium-sized cities such as Maastricht, Breda and 's-Hertogenbosch received substantial subsidies for cultural heritage preservation. Because urban development in the Middle Ages was also very concentrated in space, it is not too surprising that listed buildings and the related investments in cultural heritage are very concentrated in space.

\section{Econometric framework and data \\ A. $\quad$ Estimation procedure and identification}

We are interested in the causal effect of investments in cultural heritage, denoted by $z_{n t}$, on house prices or housing services, denoted by $y_{\text {int }}$, where $i$ refers to a property in neighbourhood $n$, and $t$ is the transaction year. We proxy for housing services of non-eligible houses using the maintenance state of the house. The basic specification yields:

$$
y_{i n t}=\alpha z_{n t}+\beta x_{i t}+\theta_{t}+\epsilon_{i n t},
$$

where $\alpha$ and $\beta$ are parameters to be estimates, $z_{n t}$ and $x_{i t}$ are referring to cumulative investments and house characteristics respectively, $\theta_{t}$ are year fixed effects, and $\epsilon_{\text {int }}$ is an identically and independently distributed error term. The cumulative investments in $z_{n t}$ year $t$ in a certain neighbourhood $n$ in year $t$ are given by:

$$
z_{n t}=\sum_{s=\underline{t}}^{t} \sum_{m=1}^{M} \omega_{n m} c_{m s}
$$

where $\underline{t}$ is the start year of the study period, $c_{m s}$ is the investment density in neighbourhood $m$, where $m=1, \ldots, M$ in year $s$, and $\omega_{n m}$ denotes a spatial weight. We emphasise that $z_{n t}$ captures the cumulative effects over time of investments in cultural heritage, which implies that the effects of investments have a permanent effect on house prices and the maintenance level. We also assume that investments in a specific project occur if the specific project is finished and are zero otherwise. We focus on effects of investments in the same neighbourhoods, so $\omega_{n m}=1(n=m)$. In the sensitivity analysis, we will investigate whether there are spatial spillovers. ${ }^{10}$

${ }^{10}$ It has been argued that external effects of amenities are continuous over space. Rossi-Hansberg et al. (2010) use semiparametric methods to estimate a distance decay function. However, although the 
If investments in cultural heritage would be randomly allocated over space, we would identify a causal effect of $\alpha$. However, listed buildings may be disproportionally located in attractive areas (e.g. city centres), which may imply a correlation between $\epsilon_{\text {int }}$ and $z_{n t}$ and this would lead to an overestimate of $\alpha$. We therefore employ a first-difference approach, where the change in the dependent variable $\Delta y_{\text {int }}$ is regressed on the change in the investment potential $\Delta z_{n t} .{ }^{11}$ This approach implies that we control for all unobserved timeinvariant housing and neighbourhood attributes. To control for changes to the house (e.g. changes in house size that disproportionally occur outside historic districts due to restrictions), we will also include changes in housing attributes $\Delta x_{i t}$, implying:

$$
\Delta y_{\text {int }}=\alpha \Delta z_{n t}+\beta \Delta x_{i t}+\Delta \theta_{t}+\Delta \epsilon_{\text {int }} \text {. }
$$

Note that if we would have two transactions for each property, the above equation would deliver identical estimates compared to a specification where we would include property fixed effects. Because we will rely on unbalanced panel data, we emphasise that $\Delta$ indicates differences over multiple years, as properties are usually not sold every year. Hence, we analyse the difference in variables of interest of the same property at two different dates. ${ }^{12}$

The crucial identifying assumption for consistent estimation of $\alpha$ in the above equation is that unobserved trends are uncorrelated with the change in treatment $\Delta z_{n t}$. This assumption may be problematic, e.g. because of trends in gentrification in historic city centres. The second concern is that $z_{n t}$ is measured with error. It might be that $z_{n t}$ includes substantial investments to the interior of the building, which are expected not to lead to external benefits. Furthermore, if anticipation effects are important, or when part of the benefits accrue during the renovation process, this implies a measurement error that will bias the estimated coefficient towards zero.

To deal with these issues, we construct an instrument to predict the change in investments that should be uncorrelated to local shocks. We use national changes in spending on cultural heritage to predict local changes in cultural heritage investments using information on the (time-invariant) stock of listed buildings, in the spirit of Bartik (1991), Saks (2008) and Moretti (2010), among others. The identifying assumption is that unobserved trends are uncorrelated with the stock of listed buildings in the start year of the study period, denoted by $\underline{t}$. As described in the previous section, the national government launched several subsidy programmes which differ vastly over time in terms of budget,

semiparametric econometric approach clearly offers flexibility and does not put any restrictions on the functional form of the spatial decay of the investments, Rossi-Hansberg et al. (2010) only can focus on the effects of the closest impact area. This seems a valid procedure if there are a few impact areas, so that one property is not influenced by multiple investment projects. However, in our application, the house price can be influenced by many proximate investments in cultural heritage. Furthermore, we only have investment data available at the neighbourhood level.

${ }^{11}$ Note that the change in the dependent variable can only be observed between two points in time at which the property is sold. For this reason the method is often referred to as the repeat-sales approach.

${ }^{12}$ Although we consider the repeat-sales estimator as the preferred estimator because it controls for all time-invariant housing attributes, we will also test whether our results are robust to the use of a fixed effects estimator (see Table B5, Appendix B). 
which implies that the predicted investments of each listed object to receive money changes considerably over the years. We then calculate the predicted investments $e_{n t}$ as:

$$
e_{n t}=\sum_{s=\underline{t}}^{t} \sum_{m=1}^{M} \frac{\ell_{m \underline{t}}}{L_{m \underline{t}}} \omega_{n m} C_{t},
$$

where $C_{t}$ is the total money spent on cultural heritage subsidies in year $t, \ell_{m \underline{t}}$ is the number of listed buildings in neighbourhood $m$ in year $\underline{t}$, and $L_{m} \underline{t}$ is the total number of listed buildings in the listed building register in year $\underline{t}$. Equation (9) implies that we estimate the predicted share of the national budget that is spent in neighbourhood $n$, based on the initial stock of listed buildings. Hence, if an area has initially more cultural heritage, the probability that it will receive subsidies is higher. The first stage is then given by:

$$
\Delta z_{n t}=\tilde{\alpha} \Delta e_{n t}+\tilde{\beta} \Delta x_{i t}+\Delta \tilde{\theta}_{t}+\Delta \tilde{\epsilon}_{i n t},
$$

where the $\sim$ indicate first-stage coefficients. Note that the second stage will be identical to equation (8), except for the fact that we include the predicted value of $\Delta z_{n t}$.

It seems plausible to suppose that the instrument is uncorrelated to different sources of measurement error in $z_{n t}$ and mitigates the problem of unobserved trends. However, one may argue that listed buildings are not randomly distributed over space, but are disproportionally located in city centres of larger cities. It might therefore be that the stock of listed buildings in year $\underline{t}$ is correlated to unobserved price trends (e.g. the fact that city centre living has gained increased attention in recent years). To alleviate this problem, we include neighbourhood fixed effects $\eta_{n}$. The inclusion of fixed effects at a low level of spatial aggregation will partly solve the problem of unobserved trends, but definitely leaves the option open that $\Delta \epsilon_{i n t}$ is still correlated to $\Delta e_{n t}$ if price trends are nonlinear. We therefore also will include a function of the number of listed buildings $\ell_{n \underline{t}}$ interacted with a flexible time trend:

$$
\Delta y_{i n t}=\alpha \Delta z_{n t}+\beta \Delta x_{i t}+\Delta \theta_{t}+\eta_{n}+\Upsilon\left(\ell_{n \underline{t}},(t-\underline{t})\right)+\Delta \epsilon_{\text {int }},
$$

with:

$$
\Upsilon\left(\ell_{n \underline{t},},(t-\underline{t})\right)=\sum_{q=1}^{\mathcal{P}} \sum_{p=1}^{\mathcal{P}} \rho_{q p} \ell_{n \underline{t}}^{q}(t-\underline{t})^{p},
$$

where $\mathcal{P}$ denotes the order of the polynomial, $q=1, \ldots, \mathcal{P}$ and $p=1, \ldots, \mathcal{P}$, and $\rho_{q r}$ are parameters to be estimated. $\Upsilon(\cdot)$ should be flexible enough to capture all price trends that are correlated to the stock of listed buildings in $n$ in $\underline{t}$. On the other hand, when $\Upsilon(\cdot)$ is fully nonparametric in the sense that it changes discretely over time, there would be perfect multicollinearity with the instrument $e_{n t}$. In practice, this will imply that we assume that unobserved trends that are correlated with $\ell_{n t}$ are reasonably smooth over time, so that they are captured by $\Upsilon(\cdot)$. For most demographic trends that may be correlated to $e_{n t}$, such as gentrification, this is most likely the case. Note that these trends may also pick up some of the 
identifying variation related to changes in the predicted investments $e_{n t}$, which may lead to an underestimate of $\alpha$.

Although we think the above approach is a convincing strategy to identify a causal effect of cultural heritage investments on the maintenance state and prices, we will extensively check for robustness in the sensitivity analysis, e.g. by focusing on a shorter time period and using a different identification strategy (see Sections VI.B and VI.C).

\section{B. Data and descriptives}

Our analysis relies upon two datasets. The first contains investments in cultural heritage from 1971-2011 for which funding from the national government is requested. The data on investment in cultural heritage that we use are from the RCE. They refer to renovation of listed buildings. At the level of individual objects we have information on the total investment, the total amount of subsidy provided, the date when the work was started and the date when it was finished. The investments are also accompanied by a short description. Based on this description we remove investments that entirely refer to renovations of the interior (almost 7 percent of the observations), because we do not expect that these renovations will have any external effects on the surrounding neighbourhood. See Appendix A for more information on this selection.

It should be noted that our investment data only cover projects for which a subsidy was given. These data do not include private investments for which no additional funding is requested. However, because eligible buildings have a high probability to receive subsidies when they apply for subsidies, there is hardly an incentive not too apply for subsidies on renovations, in particular for larger investments. Furthermore, we think it is unlikely that investors would not know about the programme given its large scale. Our data is therefore expected to capture most of the investments in cultural heritage. We should also mention that we consider only subsidies for national listed buildings. Buildings are sometimes only listed by local governments. Specific subsidies for the latter type of structures may then be provided by local governments. However, anecdotal evidence suggests that these programmes are of very limited size relative to the national programmes that we study here.

We group the investments by meaningful neighbourhoods, based on the most detailed definition of neighbourhoods used by Statistics Netherlands. The median number of inhabitants per neighbourhoods is 665 and the median size is 0.85 square kilometres. The investment data is positively skewed: some areas with a large number of listed buildings receive substantial investments (e.g. the historic city centre of Amsterdam) whereas many others receive small amounts or nothing. To avoid the problem that our results are driven by

a few impact areas, we exclude the neighbourhoods that have received more than $€$ $2,000,000$ per square kilometre in one year once during the entire study period, so that 
approximately 2.5 percent of the neighbourhoods is excluded. We investigate the robustness of the results to this particular assumption in Appendix B (see Table B6).13

The second dataset contains information on more than two million housing transactions between 1985 and 2011. The data is obtained from the NVM (Dutch Association of Real Estate Agents) and contain information on the large majority (about 70 percent) of all private housing transactions. We notice that we do not have information on rents. Data on rents would not provide any information on the economic effects of cultural heritage investments, as in the Netherlands about 80 percent of the rental transactions refer to rent-controlled markets. For every transaction we know the transaction price, the exact address and location, the size, number of rooms, construction year and maintenance quality, among other things. We omit transactions with prices that are above $€ 1$ million or below $€ 25,000$ and have a price per square meter which is above $€ 5,000$ or below $€ 500$. We furthermore leave out transactions that refer to properties that are larger than 250 square meters or smaller than 25 square meters. These selections refer to less than one percent of the data and do not influence our results. Moreover, because we are interested in the external effects of investments in cultural heritage, we exclude transactions of residential properties that are listed (so are directly eligible for subsidies).

Table 1 reports descriptive statistics. ${ }^{14}$ It can be shown that the full sample and repeatsales sample are similar. There are, however, some notable differences. First, the house price is about 12 percent lower. This may be because the share of apartments is higher, which are usually cheaper. Of course, the share of recently constructed houses in the repeat-sales sample is lower, because the probability that they are transacted more than once is lower. More importantly, the average investments in cultural heritage are about the same (about $€$ 85,000 per $\mathrm{km}^{2}$ ). The predicted investments are also very similar between the full sample and repeat-sales sample. In Figure 3 we plot the house price trends for our study period. It is shown that the price trend of the full sample and repeat-sales sample are very similar and only deviate a little in the last years.

It appears that for the state of maintenance, about 80 percent has a value equal to 0.75 . This may either indicate a maintenance score of 0.75 or a missing value (when the realtors did not fill this variable, the value is 0.75 ). Because this will lead to a very noisy dependent variable, we only focus on observations that have a score that deviates from 0.75 for either the inside maintenance quality or outside maintenance quality. The idea is that realtors will have filled in both indicators or none. ${ }^{15}$ In Table 1 , one may see that the share of missing observations for the state of maintenance is then 67 percent.

\footnotetext{
${ }^{13}$ One may also focus on a specific (large) investment (see e.g. Van Duijn et al., 2014). However, we are interested in the average effect of cultural heritage investments, and not in the effect of some specific projects.

${ }^{14}$ In Table B1, Appendix B, we report the summary statistics for yearly changes in the variables in our dataset.

${ }^{15}$ It should be noted that if we would include all maintenance scores of 0.75 , the results are essentially the same (see Section IV.B).
} 
TABLE 1 - KEY DESCRIPTIVE STATISTICS

\begin{tabular}{|c|c|c|c|c|c|c|c|c|}
\hline & \multicolumn{4}{|c|}{ Full sample } & \multicolumn{4}{|c|}{ Repeat-sales sample } \\
\hline & Mean & Std.dev. & Min & Max & Mean & Std.dev. & Min & Max \\
\hline House price (in $€$ ) & 192,847 & 113,364 & 25,000 & $1,000,000$ & 169,755 & 93,549 & 25,000 & $1,000,000$ \\
\hline Investments (in million $€$ per $\mathrm{km}^{2}$ ) & 0.089 & 0.436 & 0.000 & 12.330 & 0.080 & 0.389 & 0.000 & 12.330 \\
\hline Subsidies (in million $€$ per $\mathrm{km}^{2}$ ) & 0.033 & 0.161 & 0.000 & 3.920 & 0.030 & 0.147 & 0.000 & 3.920 \\
\hline Targeted buildings $\left(\right.$ per $\left.\mathrm{km}^{2}\right)$ & 0.594 & 3.201 & 0.000 & 177.694 & 0.529 & 2.909 & 0.000 & 177.694 \\
\hline Predicted investments (in million $€$ per $\mathrm{km}^{2}$ ) & 0.040 & 0.452 & 0.000 & 30.842 & 0.032 & 0.367 & 0.000 & 30.842 \\
\hline Number of listed buildings $1985\left(\right.$ per $\mathrm{km}^{2}$ ) & 3.247 & 27.420 & 0.000 & $1,889.311$ & 3.023 & 24.665 & 0.000 & 759.874 \\
\hline Size $\left(\right.$ in $\left.m^{2}\right)$ & 118.803 & 37.321 & 26.000 & 250.000 & 108.830 & 33.293 & 26.000 & 250.000 \\
\hline Rooms & 4.369 & 1.294 & 0.000 & 25.000 & 4.112 & 1.217 & 0.000 & 17.000 \\
\hline Central heating & 0.903 & 0.296 & & & 0.920 & 0.272 & & \\
\hline Maintenance level - inside & 0.784 & 0.248 & 0.000 & 1.000 & 0.822 & 0.226 & 0.000 & 1.000 \\
\hline Maintenance level - outside & 0.794 & 0.224 & 0.000 & 1.000 & 0.808 & 0.206 & 0.000 & 1.000 \\
\hline Maintenance level - missing & 0.670 & 0.470 & & & 0.719 & 0.449 & & \\
\hline House type - apartment & 0.253 & 0.435 & & & 0.346 & 0.476 & & \\
\hline House type - terraced & 0.323 & 0.468 & & & 0.334 & 0.472 & & \\
\hline House type - semi-detached & 0.289 & 0.453 & & & 0.247 & 0.431 & & \\
\hline House type - detached & 0.134 & 0.341 & & & 0.073 & 0.260 & & \\
\hline Garage & 0.348 & 0.476 & & & 0.257 & 0.437 & & \\
\hline Garden & 0.664 & 0.472 & & & 0.623 & 0.485 & & \\
\hline Construction year < 1945 & 0.229 & 0.420 & & & 0.210 & 0.408 & & \\
\hline Construction year 1945-1960 & 0.075 & 0.263 & & & 0.074 & 0.262 & & \\
\hline Construction year 1961-1970 & 0.168 & 0.374 & & & 0.201 & 0.401 & & \\
\hline Construction year 1971-1980 & 0.192 & 0.394 & & & 0.200 & 0.400 & & \\
\hline Construction year 1981-1990 & 0.156 & 0.363 & & & 0.175 & 0.380 & & \\
\hline Construction year 1991-2000 & 0.132 & 0.338 & & & 0.124 & 0.330 & & \\
\hline Construction year $>2000$ & 0.049 & 0.216 & & & 0.016 & 0.124 & & \\
\hline Year of observation & 2,002 & 5.907 & 1,985 & 2,011 & 2,002 & 5.673 & 1,985 & 2,011 \\
\hline
\end{tabular}

Notes: The number of observations for the full sample is 2,104,012 and for the repeat-sales sample it is 656,744 . For the corrected maintenance score, the number of observations is respectively 695,046 and 184,430. We exclude observations in areas that have faced changes in investments larger than $€ 2$ million per square kilometre in one year once during the study period.

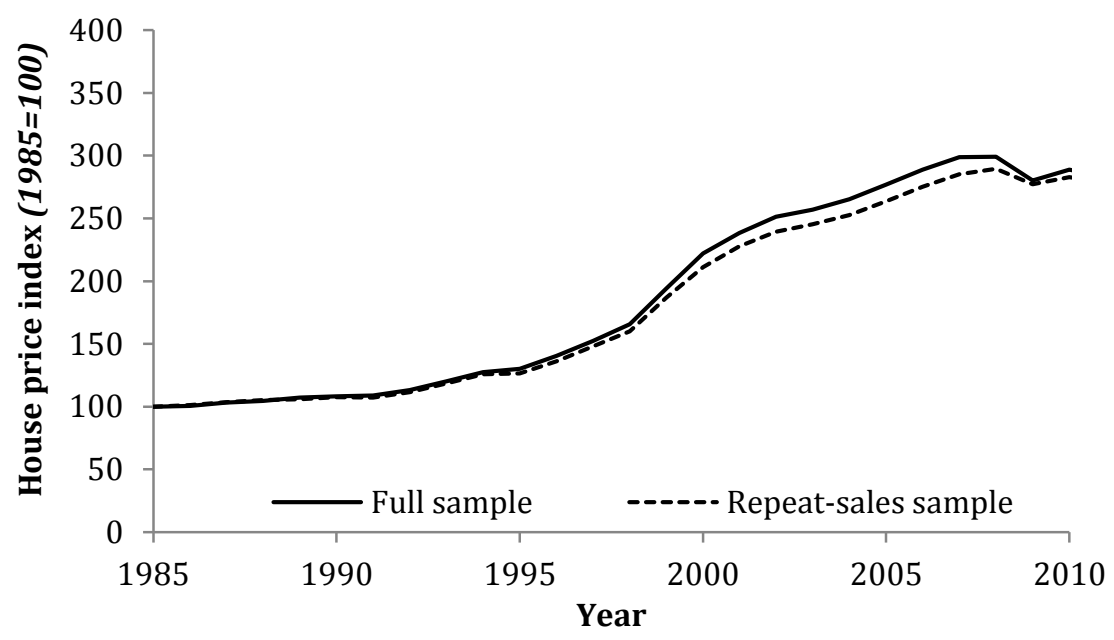

FIGURE 3 - HOUSE PRICE TRENDS 

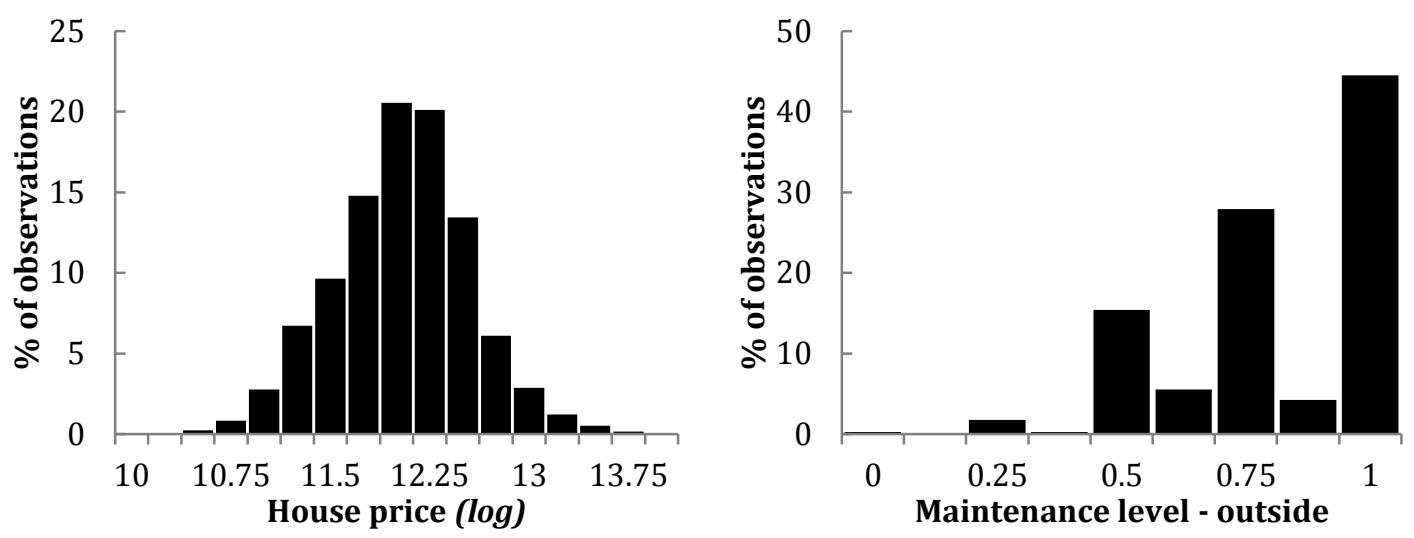

FIGURE 4 - HISTOGRAMS OF VARIABLES OF INTEREST Note: The right panel only includes observations for which the outside or inside maintenance level deviates from 0.75 .

Figure 4 presents histograms of the dependent variables we intend to use. The distribution of log house prices follows approximately a normal distribution (left-panel). The distribution of the outside state of maintenance is not normally distributed and it seems that realtors tend to round maintenance scores to $0.5,0.75$ or 1 . As long as this rounding error is random, this will not affect the consistency of our results.

\section{Results}

\section{A. Baseline results - house prices}

We start analysing the effects of investments in cultural heritage on house prices. In Table 2, we report the main regression results. We consider the impact of a one million euro increase in investments per square kilometre. The average size of investment projects is about $€$ 250,000 (with a standard deviation of $€ 782,000$ ), and the neighbourhood median size is 0.85 square kilometres, so the results can be interpreted as the effect of multiple projects in a neighbourhood (which often happens) or the effect of a single relatively large investment project. ${ }^{16}$ In all specifications, the standard errors are clustered at the neighbourhood level.

In column (1) we estimate a naïve regression of the change in house price on the change in investments, while controlling for national price trends. The results seem to suggest that a million euro increase in investments per square kilometre increases house prices by 1.82 percent. When we include housing attributes in column (2), the coefficient is very similar, albeit slightly lower. The control variables have plausible signs. Doubling the house size leads to an increase in the price of about 8 percent. The number of rooms, the maintenance quality

${ }^{16}$ Of course, we may also have investigated the effects of an average investment project, but this will not impact the qualitative conclusions. 
TABLE 2 - BASELINE RESULTS FOR HOUSE PRICES

Dependent variable: $\triangle$ price $(\mathrm{log})$

\begin{tabular}{|c|c|c|c|c|c|c|}
\hline & (1) & (2) & (3) & (4) & (5) & (6) \\
\hline & OLS & OLS & 2SLS & 2SLS & 2SLS & 2SLS \\
\hline$\Delta$ Investments (in million $€$ per $\mathrm{km}^{2}$ ) & $\begin{array}{l}0.0182^{* * *} \\
(0.00546)\end{array}$ & $\begin{array}{l}0.0152^{* * *} \\
(0.00497)\end{array}$ & $\begin{array}{l}0.0332^{* * *} \\
(0.00948)\end{array}$ & $\begin{array}{l}0.0297^{* *} \\
(0.0120)\end{array}$ & $\begin{array}{c}0.0168^{* *} \\
(0.00771)\end{array}$ & $\begin{array}{c}0.0539 * * * \\
(0.0112)\end{array}$ \\
\hline$\Delta$ House size $(\log )$ & & $\begin{array}{c}0.114^{* * *} \\
(0.00443)\end{array}$ & $\begin{array}{c}0.114^{* * *} \\
(0.00443)\end{array}$ & $\begin{array}{c}0.113^{* * *} \\
(0.00401)\end{array}$ & $\begin{array}{c}0.113^{* * *} \\
(0.00400)\end{array}$ & $\begin{array}{l}0.0960^{* * *} \\
(0.00555)\end{array}$ \\
\hline$\Delta$ Rooms & & $\begin{array}{l}0.00226^{* * *} \\
(0.000404)\end{array}$ & $\begin{array}{l}0.00229 * * * \\
(0.000405)\end{array}$ & $\begin{array}{l}0.00350^{* * *} \\
(0.000346)\end{array}$ & $\begin{array}{l}0.00348^{* * *} \\
(0.000346)\end{array}$ & $\begin{array}{l}0.00224^{* * *} \\
(0.000454)\end{array}$ \\
\hline$\Delta$ Central heating & & $\begin{array}{l}0.0766^{* * *} \\
(0.00176)\end{array}$ & $\begin{array}{l}0.0763^{* * *} \\
(0.00178)\end{array}$ & $\begin{array}{l}0.0591 * * * \\
(0.00121)\end{array}$ & $\begin{array}{l}0.0591^{* * *} \\
(0.00121)\end{array}$ & $\begin{array}{l}0.0474^{* * *} \\
(0.00155)\end{array}$ \\
\hline$\Delta$ Maintenance level - inside & & $\begin{array}{c}0.252^{* * *} \\
(0.00321)\end{array}$ & $\begin{array}{c}0.252^{* * *} \\
(0.00321)\end{array}$ & $\begin{array}{c}0.243^{* * *} \\
(0.00283)\end{array}$ & $\begin{array}{c}0.243^{* * *} \\
(0.00283)\end{array}$ & $\begin{array}{c}0.269 * * * \\
(0.00393)\end{array}$ \\
\hline$\Delta$ Maintenance level - outside & & $\begin{array}{l}0.0747^{* * *} \\
(0.00326)\end{array}$ & $\begin{array}{l}0.0747^{* * *} \\
(0.00326)\end{array}$ & $\begin{array}{l}0.0671^{* * *} \\
(0.00293)\end{array}$ & $\begin{array}{l}0.0671^{* * *} \\
(0.00293)\end{array}$ & $\begin{array}{l}0.0457^{* * *} \\
(0.00404)\end{array}$ \\
\hline$\Delta$ Maintenance level - missing & & $\begin{array}{c}0.271^{* * *} \\
(0.00271)\end{array}$ & $\begin{array}{c}0.271^{* * *} \\
(0.00271)\end{array}$ & $\begin{array}{c}0.256^{* * *} \\
(0.00249)\end{array}$ & $\begin{array}{c}0.256^{* * *} \\
(0.00248)\end{array}$ & $\begin{array}{c}0.261^{* * *} \\
(0.00345)\end{array}$ \\
\hline$\Delta$ Year fixed effects (27) & Yes & Yes & Yes & Yes & Yes & Yes \\
\hline Neighbourhood fixed effects $(7,080)$ & No & No & No & Yes & Yes & Yes \\
\hline Trend of listed building density, $\Upsilon(\cdot)$ & No & No & No & No & Yes & Yes \\
\hline $\begin{array}{l}\text { Number of observations } \\
R^{2}\end{array}$ & $\begin{array}{c}360,602 \\
0.813\end{array}$ & $\begin{array}{c}360,602 \\
0.843\end{array}$ & 360,602 & 360,602 & 360,602 & 144,152 \\
\hline First-stage $F$-statistic & & & 19.73 & 25.33 & 55.29 & 40.22 \\
\hline
\end{tabular}

Notes: We exclude observations that are in listed buildings. In Columns (3)-(6) the instrument is the change in the predicted investments. We set $\mathcal{P}=3$ in columns (5) and (6). Standard errors are in parentheses and clustered at the neighbourhood level. ${ }^{* * *} \mathrm{p}<0.01,{ }^{* *} \mathrm{p}<0.05,{ }^{*} \mathrm{p}<0.1$.

and whether the house has central heating all imply a (strong) positive price effect. Note also that when maintenance quality is missing, prices are higher, suggesting that realtors do not always report when houses are well-maintained.

Our results may be biased if unobserved price trends are correlated with investments in cultural heritage. We therefore instrument the change in investments with the change in the predicted investments. The first-stage results are reported in Table B2, Appendix B. The instrument is strong and relevant, as the first-stage $F$-statistic is always well above the ruleof-thumb value of 10 . The first-stage results suggests that a million euro per square kilometre increase in the predicted investments increase investments by 0.384 million euro per square kilometre. Note that this coefficient is much smaller than one, so the actual investments are usually lower than predicted. This is not too surprising, as some very large investments are made in (large) county estates (e.g. Kasteel de Haar) with relatively few properties in the neighbourhood, which implies that the remaining listed buildings receive fewer investments than predicted. Furthermore, we exclude neighbourhoods that have received these very large investments. 
In column (3), Table 2, the coefficient suggests a positive price effect of investments in cultural heritage on house prices: a one million euro increase in investments per square kilometre leads to an increase in house prices of 3.32 percent. One may observe that the coefficient is higher than the OLS estimates, which suggests that the instrumental variables approach addresses, at least to some extent, the downward bias caused by the measurement error in the investments variable. However, this approach may not fully address the potential correlation with unobserved shocks because areas that had more listed buildings in 1985 may have different price trends from neighbourhoods with fewer listed buildings. In column (4) we therefore include neighbourhood fixed effects, leading to a very similar price effect of cultural heritage investments. Column (5) also controls for a flexible trend in the listed building density by including a polynomial function of the listed building density in 1985 interacted with the time trend. ${ }^{17}$ So, this approach controls for all smooth time-varying unobservables that are correlated with the number of listed buildings in a neighbourhood, but it may also capture some of the identifying variation related to changes in the predicted investments. The coefficient is now somewhat lower: a million euro increase in investments per square kilometre leads to an increase in prices of 1.68 percent. One might argue that most of the identifying variation comes from observations after 2000, as fluctuations in national budgets were more pronounced in the last decade of our sample (see Figure 1). In column (6), we therefore only include observations for which both transactions occur after 2000. This also increases the probability that the flexible function of number of listed buildings and time picks up unobserved shocks, and because the national investments in listed buildings were much more volatile, it is now unlikely that the polynomial trends capture the identifying variation related to the instrument. Although this greatly reduces the number of observations, the coefficient is statistically significant at the one percent level. The impact of investments in cultural heritage is now higher: a one million euro increase in investments leads to an increase in prices of 5.39 percent. Hence, this might indicate that the previous estimates are underestimates.

Based on these results, we conclude that there is a price effect of investments in cultural heritage on house prices. However, we do not yet know whether this price effect is mainly due to the direct investments in cultural heritage, or via the increased housing quality of neighbours. If the latter is the case, the maintenance state should have been increased due to the investments, which we will test in the next subsection. If we are only interested in the direct effect of investments on prices, one may argue that we should also control for the average maintenance quality of the neighbourhood. We have calculated the average maintenance quality of houses that are sold in each neighbourhood in each year and have included that in the regressions (see Table B4, Appendix B). Although the coefficient of

17 We set the order of the polynomial to three and will check robustness of this choice in the sensitivity analysis. 
neighbourhood maintenance quality is positive and statistically significant, the coefficient related to investments is virtually unchanged. ${ }^{18}$

\section{B. $\quad$ Baseline results - state of maintenance}

We investigate whether public investments in cultural heritage have implied a change in the maintenance level of the exterior of the house, as a proxy for changes in the provision of housing services. Because maintenance quality is often missing, we have a substantially lower number of observations compared to the price regressions. Table 3 reports the results. In column (1), we provide a simple regression of the change in the maintenance level on the change in investments. The results suggest that there is no statistically (and economically) significant effect of investments on the state of maintenance. When we control for the change in house size and the number of rooms, the coefficient is very similar (column (2)). Due to endogeneity issues, we instrument for investments with the predicted investments. In Table B3, Appendix B, we report the first-stage estimates, which are almost identical to the first stages of the house price regressions despite the lower number of observations. In column (3), Table 3, the coefficient implies that a standard deviation increase in investments lead to an increase in the maintenance score of 1.88 percentage points. The effect is again statistically insignificant. In column (4) we add neighbourhood fixed effects, so we identify the effect of investments in cultural heritage of deviations from the general trend in prices in each neighbourhood. The coefficient is statistically insignificant again, also if we control for a flexible trend of the number of listed buildings in a neighbourhood in column (5). Because most of the fluctuations in public spending on cultural heritage occur after the year 2000, in column (6) we only include observations for which both transaction occur after the year 2000. The results confirm that investments in cultural heritage did not lead to changes in the state of maintenance, which suggests that social interaction effects are not very important in this case.

That is, our results are consistent with our theoretical model when $\rho>0$ and $\psi=0$. Hence, the consumption of (own) housing services and quality of buildings in the neighbourhoods do not seem to be perfect substitutes. This is also confirmed by the regressions that control for average maintenance quality in the neighbourhood, which lead to almost identical price effects of investments.

One may argue that because we have a much lower number of observations, it might be a matter of efficiency that we cannot detect an effect of investments on the maintenance state. However, except for the coefficient presented in column (6), the implied impact of the investments is very close to zero with reasonably small standard errors, suggesting that the absence of a statistically significant effect it is not an issue of efficiency. We will subject this conclusion to some robustness checks in the Section VI.B.

18 The results are reported in Table B4, Appendix B. We note that one should be careful with interpretation, because neighbourhood maintenance quality may be endogenous, as it may be correlated to unobserved neighbourhood-specific traits. 
TABLE 3 - BASELINE RESULTS FOR MAINTENANCE LEVEL

Dependent variable: $\Delta$ Maintenance level - outside

\begin{tabular}{|c|c|c|c|c|c|c|}
\hline & (1) & (2) & (3) & (4) & (5) & (6) \\
\hline & OLS & OLS & 2SLS & 2SLS & 2SLS & 2SLS \\
\hline$\Delta$ Investments (in million $€$ per $\mathrm{km}^{2}$ ) & $\begin{array}{c}0.00178 \\
(0.00545)\end{array}$ & $\begin{array}{c}0.00248 \\
(0.00542)\end{array}$ & $\begin{array}{c}0.0171 \\
(0.0189)\end{array}$ & $\begin{array}{c}0.0262 \\
(0.0160)\end{array}$ & $\begin{array}{c}0.00892 \\
(0.0133)\end{array}$ & $\begin{array}{l}0.0793 \\
(0.143)\end{array}$ \\
\hline$\Delta$ House size $(\log )$ & & $\begin{array}{l}0.214^{* * *} \\
(0.0182)\end{array}$ & $\begin{array}{l}0.215^{* * *} \\
(0.0182)\end{array}$ & $\begin{array}{l}0.207^{* * *} \\
(0.0184)\end{array}$ & $\begin{array}{l}0.207^{* * *} \\
(0.0184)\end{array}$ & $\begin{array}{l}0.200^{* * *} \\
(0.0324)\end{array}$ \\
\hline$\Delta$ Rooms & & $\begin{array}{c}-0.000484 \\
(0.00144)\end{array}$ & $\begin{array}{r}-0.000530 \\
(0.00144)\end{array}$ & $\begin{array}{c}0.00176 \\
(0.00154)\end{array}$ & $\begin{array}{c}0.00180 \\
(0.00154)\end{array}$ & $\begin{array}{c}0.00209 \\
(0.00231)\end{array}$ \\
\hline$\Delta$ Year fixed effects (27) & Yes & Yes & Yes & Yes & Yes & Yes \\
\hline Neighbourhood fixed effects $(7,080)$ & No & No & No & Yes & Yes & Yes \\
\hline Trend of listed building density, $\Upsilon(\cdot)$ & No & No & No & No & Yes & Yes \\
\hline $\begin{array}{l}\text { Number of observations } \\
R^{2}\end{array}$ & $\begin{array}{c}42,728 \\
0.023\end{array}$ & $\begin{array}{c}42,728 \\
0.031\end{array}$ & 42,728 & 42,728 & 42,728 & 17,326 \\
\hline First-stage $F$-statistic & & & 51.77 & 181.1 & 389 & 19.09 \\
\hline
\end{tabular}

Notes: We exclude observations that are in listed buildings. In Columns (3)-(6) the instrument is the change in the predicted investments. We set $\mathcal{P}=3$ in Column (5) and (6). Standard errors are in parentheses and clustered at the neighbourhood level. ${ }^{* * *} \mathrm{p}<0.01,{ }^{* *} \mathrm{p}<0.05,{ }^{*} \mathrm{p}<0.1$.

\section{Counterfactual analysis}

To gain a better understanding on the quantitative implications of the results, we conduct a counterfactual simulation using the baseline results. It should be noted that the results of this counterfactual analysis should be interpreted with caution, because we have to make several simplifying (and sometimes somewhat crude) assumptions to be able to come up with an estimate of the total external benefits of investments in cultural heritage. Furthermore, it is important to recognise that these results crucially depend on the exogeneity of investments in cultural heritage. More specifically, it matters critically that investments in cultural heritage were financed from sources exclusively outside the municipality and were not at the expense of other budgets, which seems reasonable to assume. In the analysis, we again focus on properties in neighbourhood that did not receive large investments and are not listed.

Our transactions data refer to about 70 percent of owner-occupied housing stock. To calculate the number of properties that are owned, we multiply the number of properties in our data with 1.43. Second, only about 55 percent of the properties is owner-occupied (Dröes and Koster, 2014). To get an estimate of the total effect, we assume that the price effect is identical for rental properties. To include these social benefits, we have to estimate the market value of rental housing. It appears that the rental housing value is 67.9 and 69.3 percent of the median house price in respectively Amsterdam and Rotterdam (see Van Ommeren and Koopman, 2011; Van Ommeren and Van der Vlist, 2014). Based on these 
TABLE 4 - ESTIMATES OF EXTERNAL EFFECTS OF INVESTMENTS IN CULTURAL HERITAGE

\begin{tabular}{|c|c|c|c|c|}
\hline \multirow[b]{2}{*}{ Assumed price effect } & \multicolumn{2}{|c|}{ Owner-occupied houses } & \multicolumn{2}{|c|}{ All houses } \\
\hline & $1.68 \%$ & $5.39 \%$ & $1.68 \%$ & $5.39 \%$ \\
\hline External benefits, total (in million $€$ ) & $€ 1,852$ & $€ 2,890$ & $€ 5,941$ & $€ 6,979$ \\
\hline External benefits / project total (in €) & $€ 160,711$ & $€ 250,782$ & $€ 515,614$ & $€ 605,686$ \\
\hline Investments, total (in million $€$ ) & $€ 1,630$ & $€ 1,630$ & $€ 1,630$ & $€ 1,630$ \\
\hline Investments / project (in $€$ ) & $€ 141,493$ & $€ 141,493$ & $€ 141,493$ & $€ 141,493$ \\
\hline External benefits / investments & 1.14 & 1.77 & 3.64 & 4.28 \\
\hline Subsidies, total (in million $€$ ) & $€ 626$ & $€ 626$ & $€ 626$ & $€ 626$ \\
\hline Subsidies / project (in €) & $€ 54,347$ & $€ 54,347$ & $€ 54,347$ & $€ 54,347$ \\
\hline External benefits / subsidies & 2.96 & 4.61 & 9.49 & 11.14 \\
\hline \multicolumn{5}{|c|}{$\begin{array}{l}\text { Notes: We only focus on the price effects of neighbourhoods that did not receive more than } € 2 \text { million } \\
\text { investment per square kilometre in one year once during the study period and we exclude listed } \\
\text { buildings. We deflate house prices, investments and subsidies using the consumer price index, so all } \\
\text { values are in } 2011 \text { prices. We calculate the average house price per neighbourhood in } 2011 \text { prices, count } \\
\text { the number of properties in each neighbourhood and multiply that with } 1.43 \text {. We then calculate the } \\
\text { investments and subsidies in } 2011 \text { prices per square kilometre. Together with the implied price effects } \\
(1.68 \% \text { and } 5.39 \%) \text { we have all information to calculate the benefits and costs. }\end{array}$} \\
\hline
\end{tabular}

figures, we assume that the median value of rental housing is 68.5 percent of the median house price in each neighbourhood. Including rental properties will probably lead to an upper bound of the total benefits of investments in cultural heritage because the price effect on rental housing is probably lower (see equations (4) and (5) and Rossi-Hansberg et al., 2010). Third, we estimate the benefits and costs in 2011 prices, by deflating house prices, investments and subsidies by the consumer price index, obtained from Statistics Netherlands.

Table 4 reports back-of-the-envelope calculations of the total benefits of investments in cultural heritage. We first take the baseline price effect obtained from Column (5), Table 2. When we take the lower bound estimate of external effects, the total external benefits of investments in cultural heritage are 1.85 billion euro. This is more than the 1.63 billion euro investments in cultural heritage. More specifically, the results suggest that the benefits are about 14 percent higher than the costs. If we take the upper bound price effect of 5.39 percent (Column (6), Table 2), the benefits to costs ratio is 1.77. Owner-occupied houses are about 55 percent of the total housing stock. If one is willing to assume that this share is reasonably constant across space and that the price effect is identical for rental housing, we may estimate the total external benefits of investments in cultural heritage on the housing market. The calculations show that the external benefits range then from 5.94 billion euro to 6.98 billion euro. The benefits-to-costs ratios are then between 3.64 and 4.28, which even provide more convincing evidence that investments in cultural heritage generate positive benefits to society. However, because the price effects are probably lower for rental housing, 
these latter effects are best interpreted as upper bound estimates of the effects of investments in cultural heritage.

\section{Sensitivity analysis \\ A. Introduction}

In this sensitivity analysis, we investigate whether our results are robust to a wide range of robustness checks. First, we test whether the absence of a social interactions effect holds if we choose other dependent variable or when we exclude apartments. In what follows, we focus on the robustness of the house price effects and do not report the results for the maintenance state, because they remain statistically insignificant in all other specifications. Second, we pursue another identification strategy based on historic district designation to, select areas that are likely similar in unobservables. Third, we test robustness of our results to several assumptions made in the empirical set-up. Finally, we inspect the magnitude of potential spatial spillovers of the investment programme. In Appendix B, we report and discuss some additional robustness checks. We test whether the price effect is robust if we include the average maintenance level in the neighbourhood, as to provide additional evidence that the investments in cultural heritage have mainly a direct effect on prices of surrounding properties. We also estimate fixed effects models, rather than first-differencing the variables of interest and we test whether our results are sensitive to the inclusion of areas that have received large investments,

\section{B. State of maintenance}

The sensitivity analyses with respect to the state of maintenance are reported in Table 5. One might argue that for house owners occupying apartments, the possibilities to endogenously determine the maintenance level is limited. We therefore also have estimated regressions where we only focus on terraced, semi-detached and detached houses, leading to essentially the same conclusions. Hence, we do not find any evidence that public investments have led to changes in the maintenance level (see Column (1), Table 5). In Column (2), we report results when we take the overall maintenance quality (which is the average of the inside and outside state of maintenance) as dependent variable, rather than the outside maintenance quality. Again, the coefficient is statistically insignificant. Column (3) includes all data and ignores any potential measurement error in the dependent variable (so, assumes that values of 0.75 are correctly reported). The results confirm that the investments in cultural heritage seem not to be statistically significantly related to the maintenance quality of the house. In the final column, we use a dummy that indicates whether the maintenance state is above 0.75 . The coefficient related to investments remains statistically insignificant. 
TABLE $5-$ SENSITIVITY ANALYSIS FOR MAINTENANCE STATE

\begin{tabular}{|c|c|c|c|c|}
\hline & (1) & $(2)$ & (3) & $(4)$ \\
\hline & $\begin{array}{l}\text { Exclude } \\
\text { apartments }\end{array}$ & $\begin{array}{l}\text { Overall maint. } \\
\text { quality }\end{array}$ & $\begin{array}{c}\text { Include all } \\
\text { observations }\end{array}$ & $\begin{array}{l}\text { Dummy good } \\
\text { condition }\end{array}$ \\
\hline & 2SLS & $2 \mathrm{SLS}$ & $2 S L S$ & $2 \mathrm{SLS}$ \\
\hline$\Delta$ Investments (in million $€$ per $\mathrm{km}^{2}$ ) & $\begin{array}{c}-0.0158 \\
(0.0191)\end{array}$ & $\begin{array}{l}0.00892 \\
(0.0133)\end{array}$ & $\begin{array}{l}-0.00107 \\
(0.00442)\end{array}$ & $\begin{array}{l}-0.0120 \\
(0.0137)\end{array}$ \\
\hline$\Delta$ House size $(\log )$ & $0.274^{* * *}$ & $0.277^{* * *}$ & $0.0791^{* * *}$ & $0.151^{* * *}$ \\
\hline$\Delta$ Rooms & $\begin{array}{c}0.00227 \\
(0.00193)\end{array}$ & $\begin{array}{c}-0.00114 \\
(0.00149)\end{array}$ & $\begin{array}{c}-0.000182 \\
(0.000352)\end{array}$ & $\begin{array}{c}0.000209 \\
(0.000969)\end{array}$ \\
\hline$\Delta$ Year fixed effects (27) & Yes & Yes & Yes & Yes \\
\hline Neighbourhood fixed effects $(7,080)$ & Yes & Yes & Yes & Yes \\
\hline Trend of listed building density, $\Upsilon(\cdot)$ & Yes & Yes & Yes & Yes \\
\hline Number of observations & 25,424 & 42,728 & 360,602 & 360,602 \\
\hline First-stage $F$-statistic & 382.7 & 389.0 & 55.30 & 55.30 \\
\hline
\end{tabular}

\section{Identification revisited: a 'quasi-experimental' approach}

We identify the effect of investments in cultural heritage using an instrument that exploits yearly changes in the national budget for subsidies on cultural heritage. Here, we pursue an alternative 'quasi-experimental' approach based on historic district designation. The main threat to identification of a causal effect is that unobserved price trends are correlated to investments in cultural heritage. To mitigate the problem of correlated unobserved trends, we should measure the effects of investments in cultural heritage in 'comparable' neighbourhoods. Of course, the 'treatment' variable we consider, the investments in cultural heritage, is continuous, so treatment and control groups cannot be strictly defined. Nevertheless, we may focus only on neighbourhoods that are expected to have similar unobserved traits.

In the Netherlands, designation of historic district is the responsibility of the national government. The procedure for an area to be converted into a historic district (in Dutch: beschermd stadsgezicht) is prepared by the RCE. It is important to note that in contrast to the UK and the US, municipality and house owners cannot influence this process, so the location of historic districts is thought to be exogenously determined (from the house owner perspective) (Ahlfeldt et al., 2014; Koster et al., 2014). After having designated the most important historic districts (such as the city centre in Amsterdam), in 1990 the RCE compiled a shortlist with other potential historic districts, labelled as MSP-districts. This list was not 


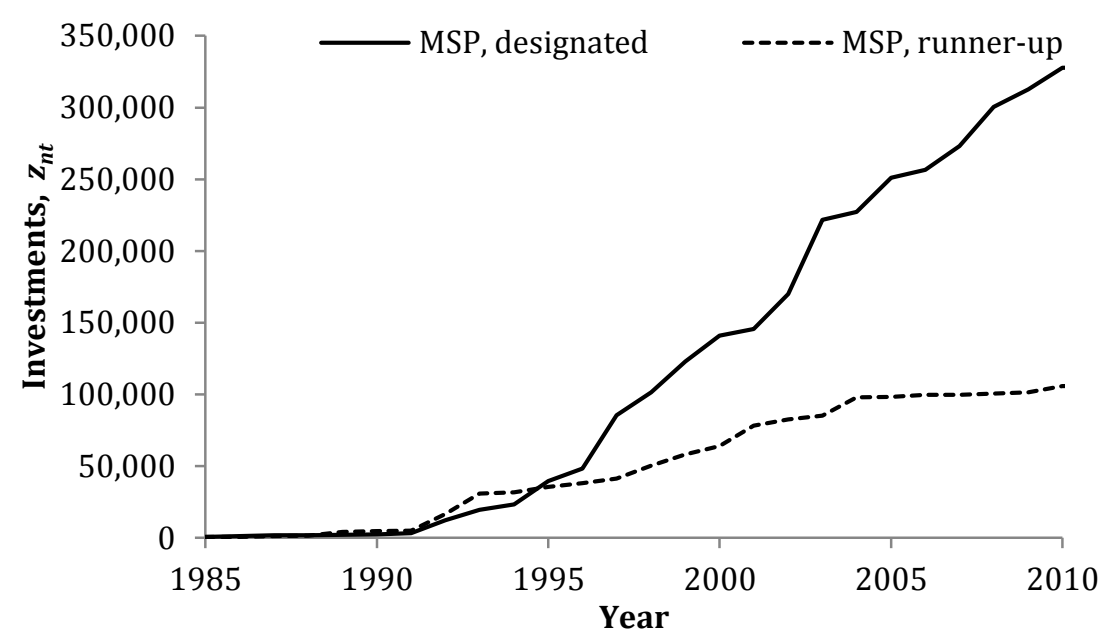

FIGURE 5 - INVESTMENTS IN DESIGNATED AND RUNNER-UP MSP-DISTRICTS Note: We calculate the cumulative investments in each year for the set of postcodes that are either in designated or runner-up MSP-districts.

made public. 129 MSP-districts are officially designated, 21 districts are still under consideration and 14 MSP districts have eventually not been qualified as historic districts. It seems reasonable to assume that the latter 'runner-up' historic districts will have similar unobserved traits as the designated historic districts. We therefore only select observations that are either in designated MSP-districts or in runner-up MSP-districts. ${ }^{19}$ Figure 5 shows that the predicted investments in designated and runner-up MSP-districts were very similar until 1995. Due to designation of historic districts after 1995, the cumulative investments probably have increased. Although historic district designation officially does not imply changes in the probability to receive subsidies and becoming a listed building, informally the probabilities to become listed and receive investments are probably higher when an area is officially designated. Because unobserved trends between designated and runner-up MSPdistricts may differ after 1995, we also estimate a specification where we only focus on designated MSP-districts.

We may pursue a repeat sales approach, as in the previous sections. However, we would have too few observations to identify the effect of interest. Instead, we include postcode fixed effects. In the Netherlands, postcode areas encompass about half a street (on average 15 households), which is comparable to a census block in the United States. The fixed effects essentially deal with all unobserved time-invariant spatial attributes (Van Ommeren and Wentink, 2012). ${ }^{20}$ We then estimate equations of the following form:

${ }^{19}$ Note that if lobbying might be a way for house owners to be placed on the list, this does not invalidate our identification strategy because we focus on observations in MSP-districts only.

20 One may worry that the baseline repeat-sales results may differ from the results obtained using a fixed-effects approach. In Appendix B we report and discuss results when using postcode fixed effects, 


$$
y_{\text {int }}=\alpha z_{n t}+\beta x_{i t}+\theta_{t}+\xi_{i}+\epsilon_{\text {int }},
$$

where $y_{\text {int }}$ is the log price of a house, $x_{i t}$ are housing attributes, including the house size, construction year, house type, and $\xi_{i}$ are postcode fixed effects. One may argue that unobserved traits may be correlated with the year in which the MSP-district is taken into consideration, which is the case if the most attractive areas are considered first. We therefore include a flexible function of interactions between the year of observation and the year in which the MSP-district has been taken into consideration, denoted by $\tau_{n \underline{t}}$. We then have:

$$
y_{\text {int }}=\alpha z_{n t}+\beta x_{i t}+\theta_{t}+\xi_{i}+\Omega\left(\tau_{n \underline{t}},(t-\underline{t})\right)+\Upsilon\left(\ell_{n t},(t-\underline{t})\right)+\epsilon_{\text {int }},
$$

with:

$$
\Omega\left(\tau_{n \underline{t},}(t-\underline{t})\right)=\sum_{q=1}^{\mathcal{P}} \sum_{p=1}^{\mathcal{P}} \sigma_{q p} \tau_{n \underline{t}}(t-\underline{t})^{p},
$$

where $\sigma_{q p}$ are parameters to be estimated. We also will include a function of the number of listed buildings $\ell_{n t}$ in year $t$ interacted with a flexible time trend. We again exclude listed buildings and the locations that have received more than $€ 2$ million investment per square kilometre in one year once during the study period.

Table 6 reports the results when we only include observations in designated and runnerup MSP-districts. In column (1) the results seem to suggest that a million euro increase in investments per square kilometre increases house prices with 4.65 percent. This effect becomes somewhat stronger if we control for housing attributes in column (2). Column (3) controls for the polynomial function $\Omega(\cdot)$, so controls for price trends that are correlated with the year in which the designation of MSP-district is taken into consideration. The price increase is then 5.04 percent for a million euro increase in investments per square kilometre. Although the effect is only statistically significant at the 10 percent level, the quantitative effect is similar to the upper bound effect found previously. The price effect is very similar if we also control for the function of the number of listed buildings in column (4). In column (5) we only include transactions that take place after 2000. Again, the coefficient is very similar. One may be worried that the runner-up districts are for some reason different from designated MSP-districts, for example because runner-up MSP-districts are sometimes relatively large rural areas (see Figure A1, Appendix A). In column (6) we therefore only focus on observations in designated historic districts, which reduces the number of observations with more than 20 percent. The price effect is then almost identical to the previous specification, which provides additional evidence that investments have implied a house price increase of properties in the neighbourhood.

Hence, despite the somewhat larger confidence intervals due to lower number of observations, this quasi-experimental set-up seems also to suggest that investments in cultural heritage have economically meaningful effects on house prices.

rather than first-differencing. The coefficients are very similar to the baseline results reported in Table 2. 
TABLE 6 - QUASI-EXPERIMENTAL APPROACH, RESULTS FOR PRICES

Dependent variable: price (log)

\begin{tabular}{lcccccc}
\hline & $(1)$ & $(2)$ & $(3)$ & $(4)$ & $(5)$ & $(6)$ \\
\cline { 2 - 7 } & OLS & OLS & OLS & OLS & OLS & OLS \\
\hline \multirow{2}{*}{ Investments (in million $€$ per $\mathrm{km}^{2}$ ) } & $0.0465^{*}$ & $0.0621^{* *}$ & $0.0504^{*}$ & $0.0556^{*}$ & $0.0554^{*}$ & $0.0559^{*}$ \\
& $(0.0262)$ & $(0.0245)$ & $(0.0264)$ & $(0.0288)$ & $(0.0297)$ & $(0.0306)$ \\
& & & & & & \\
Year fixed effects (27) & Yes & Yes & Yes & Yes & Yes & Yes \\
Postcode fixed effects & Yes & Yes & Yes & Yes & Yes & Yes \\
Housing attributes (19) & No & Yes & Yes & Yes & Yes & Yes \\
Trend of year in consideration, $\Omega(\cdot)$ & No & No & Yes & Yes & Yes & Yes \\
Trend of listed building density, $Y(\cdot)$ & No & No & No & Yes & Yes & Yes \\
& & & & & & \\
Number of observations & 23,946 & 23,946 & 23,946 & 23,946 & 18,884 & 14,914 \\
$R^{2}$ & 0.793 & 0.934 & 0.935 & 0.935 & 0.930 & 0.935 \\
\hline
\end{tabular}

Notes: We exclude observations that are in listed buildings. . The control variables are house size (log), rooms, central heating, maintenance level - inside, maintenance level - outside, maintenance level - missing, house type - terraced, house type - semi-detached, house type - detached, house type - apartment, garage garden and 8 construction-decade dummies. We set $\mathcal{P}=3$ in Columns (3), (4), (5) and (6). Standard errors are in parentheses and clustered at the neighbourhood level. ${ }^{* *} \mathrm{p}<0.05,{ }^{*} \mathrm{p}<0.1$.

\section{Identification revisited: other specifications}

In this subsection, we discuss some issues with respect to the initial identification strategy using the shift-share instrument.

First, to allow for the fact that neighbourhoods with more listed buildings have different price trends from other neighbourhoods, we include a flexible function of the number of listed buildings and time. We choose an order of the polynomial of three, which is somewhat arbitrary. In Columns (1) and (2) in Table 7 we therefore also investigate whether our results change when we include second or fourth order polynomials. It appears that the results are virtually unchanged. Hence, the order of the polynomial seems not to be very important. It should be noted that if we would include higher order polynomial functions, this would lead to severe multicollinearity. Rather than including flexible trends, we might also focus on areas that are 'comparable'. In Column (3) we only select areas with a positive number of listed buildings in 1985 and use the same identification strategy. This reduces the number of observations with 70 percent. The price effect is, however, very similar (about 2.7 percent for a million euro per square kilometre increase).

The current instrument uses the stock in 1985 to predict the amount of subsidies and the associated investments in cultural heritage. To minimise the possibility that the stock of listed buildings is correlated to pre-trends in prices, we construct the instrument also based on the number of listed buildings in 1975. The coefficient in Column (4) suggests that this will not lead to different conclusions: a million euro per square kilometre investments leads to a price change of 1.62 percent. 
TABLE 7 - SENSITIVITY ANALYSIS: IDENTIFICATION REVISITED Dependent variable: $\Delta$ price (log)

\begin{tabular}{|c|c|c|c|c|c|c|}
\hline & (1) & $(2)$ & (3) & $(4)$ & (5) & $(6)$ \\
\hline & $\begin{array}{l}\text { Polynomial, } \\
\mathcal{P}=2\end{array}$ & $\begin{array}{l}\text { Polynomial, } \\
\mathcal{P}=4\end{array}$ & $\begin{array}{c}\text { Number of } \\
\text { listed buildings } \\
1985>0 \\
\end{array}$ & $\begin{array}{c}\text { Predicted } \\
\text { investments, } \\
1975 \\
\end{array}$ & $\begin{array}{c}\text { Predicted } \\
\text { investments, } \\
\text { type-specific }\end{array}$ & $\begin{array}{c}\text { Predicted } \\
\text { investments, } \\
\text { type-specific }\end{array}$ \\
\hline & 2SLS & 2SLS & 2SLS & 2SLS & 2SLS & 2SLS \\
\hline$\Delta$ Investments (in million $€$ per $\mathrm{km}^{2}$ ) & $\begin{array}{c}0.0169^{* *} \\
(0.00776)\end{array}$ & $\begin{array}{c}0.0172^{* *} \\
(0.00790)\end{array}$ & $\begin{array}{l}0.0266^{* *} \\
(0.0124)\end{array}$ & $\begin{array}{c}0.0162^{* *} \\
(0.00753)\end{array}$ & $\begin{array}{c}0.0167^{* *} \\
(0.00751)\end{array}$ & $\begin{array}{c}0.0133 \\
(0.0260)\end{array}$ \\
\hline $\begin{array}{l}\Delta \text { Predicted investments (in million } € \\
\quad \text { per } \mathrm{km}^{2} \text { ) }\end{array}$ & & & & & & $\begin{array}{l}0.00178 \\
(0.0148)\end{array}$ \\
\hline$\Delta$ Control variables (6) & Yes & Yes & Yes & Yes & Yes & Yes \\
\hline$\Delta$ Year fixed effects (27) & Yes & Yes & Yes & Yes & Yes & Yes \\
\hline Neighbourhood fixed effects $(7,080)$ & Yes & Yes & Yes & Yes & Yes & Yes \\
\hline Trend of listed building density, $\Upsilon(\cdot)$ & Yes & Yes & No & Yes & Yes & Yes \\
\hline Number of observations & 360,602 & 360,602 & 107,990 & 360,602 & 360,602 & 360,602 \\
\hline First-stage $F$-statistic & 54.17 & 51.05 & 31.73 & 48.17 & 56.04 & 37.62 \\
\hline
\end{tabular}

Another objection one may have against the instrument is that it does not make a distinction between different types of listed buildings, which are not all eligible for different subsidy programmes. For example, there is a programme that explicitly targets castles and country estates. Areas with more castles and country estates are therefore more likely to receive these subsidies. In Appendix A we explain in more detail which programmes target different types of listed buildings. We then construct an instrument taking into account that several subsidy programmes target different types of listed buildings. Because these programmes differ vastly over time in terms of budget, this implies that the predicted investments for each listed object to receive money changes considerably over the years. In Column (5) we use the type-specific instrument, rather than the original instrument that does not take into account type-specific predicted investments. The type-specific instrument is calculated as follows:

$$
\tilde{e}_{n t}=\sum_{s=\underline{t}}^{t} \sum_{m=1}^{M} \sum_{j=1}^{J} \frac{\ell_{j m \underline{t}}}{L_{j m \underline{t}}} \omega_{n m} C_{j t},
$$

where $j=1, \ldots, J$ denotes the type of listed building.

The coefficient is then very similar to the baseline results. We also try to isolate this source of identifying variation by controlling for the general instrument used in the previous section, while using the type-specific predicted investments as the instrument. Hence, the identifying variation comes from changes in predicted investments of listed buildings due to 
changes in subsidy programmes that target different types of listed buildings. Column (6), Table 7, reports the results. The instrument seems to be strong and the point estimate is close to the baseline results. However, because the correlation between the general predicted investments and the type-specific predicted investments is 0.99 , the point estimate is very imprecise and we cannot draw strong conclusions based on these results. ${ }^{21}$

\section{E. Spatial spillovers}

We do not consider it the main purpose of this paper to investigate the spatial decay of investments in cultural heritage, mainly because we lack very accurate information on the location of (all) listed structures. Nevertheless, it may be important to investigate whether there are spatial spillovers and, more importantly, whether controlling for investments in close neighbourhoods affects the main effect. Controlling for neighbouring investments may be important when investments are correlated over space and time, because when investments in one area are associated with investments in nearby areas, this might lead to an overestimate of the impact of the investments in cultural heritage.

In Table 8 we report the results of the regression where we include a variable indicating the average investments in neighbourhoods that are within 250 meters of the own neighbourhood and a variable indicating the average investments for neighbourhoods that are between 250 and 500 meters of the own neighbourhoods. The instruments are then predicted investments and the average predicted investments in nearby neighbourhoods. ${ }^{22}$ In column (1) we only instrument investments in the own neighbourhood and control for the trend of listed building density in the own neighbourhood. The results indicate that the own investments have a positive impact on house prices: a million euro per square kilometre investments leads to a price change of 1.64 percent, which is very similar to our baseline specification. The investments in nearby neighbourhoods do not seem to impact house prices in the own neighbourhood. In column (2) we also control for trends of listed building density in the corresponding distance rings. This hardly affects the results, although investments in neighbourhoods within 250 meters of the own neighbourhood seem to have a negative impact on house prices in the own neighbourhood. However, this effect is not economically important and close to zero. The effects of nearby investments are similar when we instrument them in column (3). The instruments are then the predicted investments in 0-250 and 250-500 meters of the own neighbourhood respectively. When we only focus on transactions that take place after 2000, the main effect becomes again larger, in line with the

\footnotetext{
${ }^{21}$ We also investigate whether this result will change when we do not include fixed effects and/or time trends interacted with the stock of listed buildings and when we focus on observations for which both transactions are observed after 2000, because most of the variation in type-specific subsidies occurs after 2000. Although the point estimate is always positive and in line with previous specifications, the coefficient remains quite imprecisely estimated.

${ }^{22}$ We calculate the average investments by summing up all investments in the corresponding distance ring (based on neighbourhood centroids) and then dividing by the total area of the neighbourhoods that fall within the distance ring.
} 
TABLE 8 - SENSITIVITY ANALYSIS: SPATIAL SPILLOVERS

Dependent variable: $\Delta$ price $(\log )$

\begin{tabular}{|c|c|c|c|c|}
\hline & (1) & $(2)$ & (3) & $(4)$ \\
\hline & $\begin{array}{c}\text { Include } \\
\text { neighbouring } \\
\text { investments }\end{array}$ & $\begin{array}{c}\text { Control for trends } \\
\text { of nearby listed } \\
\text { buildings }\end{array}$ & $\begin{array}{c}\text { Instrument } \\
\text { neighbouring } \\
\text { investments } \\
\end{array}$ & $\begin{array}{l}\text { Observations } \\
\quad>2000\end{array}$ \\
\hline & 2SLS & 2SLS & 2SLS & 2SLS \\
\hline$\Delta$ Investments (in million $€$ per $\mathrm{km}^{2}$ ) & $\begin{array}{c}0.0164^{* *} \\
(0.00819)\end{array}$ & $\begin{array}{c}0.0184^{* *} \\
(0.00906)\end{array}$ & $\begin{array}{c}0.0201^{* *} \\
(0.00991)\end{array}$ & $\begin{array}{c}0.0588^{* * *} \\
(0.0107)\end{array}$ \\
\hline$\Delta$ Investments $0-250 \mathrm{~m}$ (in million $€$ per $\mathrm{km}^{2}$ ) & $\begin{array}{c}-0.0000709 \\
(0.000295)\end{array}$ & $\begin{array}{c}-0.000306^{* *} \\
(0.000156)\end{array}$ & $\begin{array}{c}-0.000324^{* *} \\
(0.000162)\end{array}$ & $\begin{array}{r}0.00979^{* * *} \\
(0.00266)\end{array}$ \\
\hline$\Delta$ Investments $250-500 \mathrm{~m}$ (in million $€$ per $\mathrm{km}^{2}$ ) & $\begin{array}{c}0.00101 \\
(0.000874)\end{array}$ & $\begin{array}{c}0.000517 \\
(0.000992)\end{array}$ & $\begin{array}{c}0.000506 \\
(0.000993)\end{array}$ & $\begin{array}{c}0.00102 \\
(0.00121)\end{array}$ \\
\hline$\Delta$ Control variables (6) & Yes & Yes & Yes & Yes \\
\hline$\Delta$ Year fixed effects (27) & Yes & Yes & Yes & Yes \\
\hline Municipality fixed effects (457) & Yes & Yes & Yes & Yes \\
\hline Neighbourhood fixed effects $(7,080)$ & Yes & Yes & Yes & Yes \\
\hline Trend of listed building density, $\Upsilon(\cdot)$ & Yes & Yes & Yes & Yes \\
\hline Trend of nearby listed building density, $\Upsilon^{\mathcal{N}}(\cdot)$ & No & Yes & Yes & Yes \\
\hline Number of observations & 360,602 & 360,602 & 360,602 & 144,152 \\
\hline Kleibergen-Paap $F$-statistic & 54.92 & 53.87 & 18.55 & 13.40 \\
\hline
\end{tabular}

baseline estimates. The investments in neighbouring areas within 250 meters now have a small, albeit statistically significant, positive effect on house prices. Hence, these results seem to suggest that the spatial decay of investments is quite strong, so that investments are mainly important in the own neighbourhood, in line with Rossi-Hansberg et al. (2010).

\section{Conclusions}

In this paper we study the impact of investments in cultural heritage on house prices in surrounding areas. From an economic point of view, a main reason for subsidising these investments is the presence of a positive external effect from the heritage on the properties of the area in which it is located. Finding a positive causal impact of such investment on surrounding house prices would therefore provide a strong argument for the subsidies given.

In this paper, we make a distinction between the direct price effect of investments in cultural heritage and the indirect effect, via changes in the consumption of housing services of properties that are not eligible for subsidies. We proxy for housing services using the maintenance state of the exterior of the house. To identify a causal effect of investments in cultural heritage, we use repeat sales and exploit variation in spending on cultural heritage 
by the national government. We further control for unobserved traits by including neighbourhood fixed effects, so we identify the effect of investments that deviate from neighbourhood-specific price trends. We also include a flexible function of the stock of listed buildings in 1985 interacted with the time trend, to control for price trends that are correlated to the concentration listed buildings in space.

Our estimation results confirm the presence of a positive external impact of investments in cultural heritage on house prices. A one million euro increase in investments per square kilometre leads to an increase in house prices of 1.5-5 percent. This seems to be mainly a direct effect of the investments in cultural heritage, rather than an indirect effect. More specifically, we cannot detect any effects of investments in cultural heritage on the maintenance state of houses, which suggests that the main impact of these investments on utility is a direct one that operates independent of the demand for housing services.

\section{References}

Ahlfeldt, G. M., and Maennig, W. (2010). Substitutability and Complementarity of Urban Amenities: External effects of Built Heritage in Berlin. Real Estate Economics, 38(2), 285-323.

Ahlfeldt, G. M., Möller, K., Waights, S., and Wendland, N. (2014). Game of Zones: The Economics of Conservation Areas. SERC Discussion Paper \#143.

Asabere, P. K., Huffman, F. E., and Mehdian, S. (1994). The Adverse Impacts of Local Historic Designation: The Case of Small Apartment Buildings in Philadelphia. The Journal of Real Estate Finance and Economics, 8(3), 225-234.

Bartik, T. J. (1991). Boon or Boondoggle? The Debate Over State and Local Economic Development Policies. In Who Benefits from State and Local Economic Development Policies? (pp. 1-16). WE Upjohn Institute for Employment Research.

Brueckner, J. K., Thisse, J. F., and Zenou, Y. (1999). Why is Central Paris Rich and Downtown Detroit Poor? An Amenity-based Theory. European Economic Review, 43(1), 91-107.

Coulson, N. E., and Lahr, M. L. (2005). Gracing the Land of Elvis and Beale Street: Historic Designation and Property Values in Memphis. Real Estate Economics, 33(3), 487-507.

Deaton, A., and Muellbauer, J. (1980). An Almost Ideal Demand System. American Economic Review, $70(3), 312-326$.

Dröes, M. I., and Koster, H. R. A. (2014). Renewable Energy and Negative Externalities: The Effect of Wind Turbines on House Prices. Tinbergen Institute Discussion Paper TI 2014-124/VIII.

Falck, O., Fritsch, M., Heblich, S., and Otto, A. (2015). Music in the Air: Estimating the Social Return to Cultural Amenities. Mimeo, University of Bristol.

Glaeser, E. L., Kolko, J., and Saiz, A. (2001). Consumer City. Journal of Economic Geography, 1(1), 27-50.

Hausman, J. A. (1981). Exact Consumer's Surplus and Deadweight Loss. American Economic Review, 71(4), 662-676.

Ioannides, Y. M. (2003). Interactive Property Valuations. Journal of Urban Economics, 53(1), 145-170.

Koster, H. R. A., Van Ommeren, J. N., and Rietveld, P. (2014). Historic Amenities, Income and Sorting of Households. Forthcoming in Journal of Economic Geography.

Leichenko, R., Coulson, N. E., and Listokin, D. (2001). Historic Preservation and Residential Property Values: An Analysis of Texas Cities. Urban Studies, 38(11), 1973-1987.

Moretti, E. (2010). Local Multipliers. American Economic Review, 100(2), 373-377. 
Navrud, S., and Ready, R. C. . (2003). Valuing Cultural Heritage: Applying Environmental Valuation Techniques to Historic Buildings, Monuments and Artifacts. Journal of Cultural Economics, 27(3-4), 287.

Patacchini, E., and Venanzoni, G. (2014). Peer Effects in the Demand for Housing Quality. Journal of Urban Economics, 83, 6-17.

Roback, J. (1982). Wages, Rents, and the Quality of Life. Journal of Political Economy, 90(6), 1257-1278.

Rossi-Hansberg, E., Sarte, P., and Owens III, R. (2010). Housing Externalities. Journal of Political Economy, 118(3), 485-535.

Saks, R. E. (2008). Job Creation and Housing Construction: Constraints on Metropolitan Area Employment Growth. Journal of Urban Economics, 64(1), 178-195.

Schaeffer, P., and Millerick, C. (1991). The Impact of Historic District Designation on Property Values: An Empirical Study. Economic Development Quarterly, 5(4), 301-312.

Van Duijn, M., Lazrak, F., Rietveld, P., and Rouwendal, J. (2012). The Effect of Brownfield Redevelopment on Surrounding Residential Areas: The Case of the Amsterdam Western Gas Factory. Mimeo, VU University Amsterdam.

Van Duijn, M., and Rouwendal, J. (2015). Sorting Based on Urban Heritage and Income: Evidence from the Amsterdam Metropolitan Area. Mimeo, VU University Amsterdam.

Van Ommeren, J. N., and Koopman, M. (2011). Public Housing and the Value of Apartment Quality to Households. Regional Science and Urban Economics, 41(3), 207-213.

Van Ommeren, J. N., and Van der Vlist, A. J. (2014). Households' Willingness to Pay for Public Housing. Mimeo, VU University Amsterdam.

Van Ommeren, J. N., and Wentink, D. (2012). The (Hidden) Cost of Employer Parking Policies. International Economic Review, 53(3), 965-978.

\section{Appendix A. Detailed description of data and sources}

\section{A.1 Listed building dataset}

We gather data from the Department of Cultural Heritage (In Dutch: Rijksdienst voor Cultureel Erfgoed, (RCE)). They provide information on all listed buildings and archaeological sites in the Netherlands. Because the data on investments only apply to listed buildings, we drop observations on archaeological sites. For less than one percent of the observations we do not have any information on the location of the building, so we remove them from the dataset. After these selections, we have information on 61,211 listed buildings. For each listed building we have information on the type (e.g. castle, religious building), the year of listing, a description of the listed building and geographic coordinates based on the address. For 27 percent of the observations, we also know the construction year. Because listed structures may be very large (e.g. country estates), do not always have an address, or the address is unknown, the location is somewhat imprecise. We therefore aggregate listed buildings up to neighbourhoods, which are the smallest spatial areas used by Statistics Netherlands. These are smaller than postcode areas or districts and comprise on average 635 households.

The procedure to become listed is not random. First, listed buildings that were constructed before 1850 were listed. This process was finished in 2000. Listed buildings that 
TABLE A1 — INVESTMENTS IN CULTURAL HERITAGE PER PROGRAMME

\begin{tabular}{llrl}
\hline Programme & Period & Spending & Targeted listed buildings \\
\hline BRRM & 1970-2003 & $€ 251,508,192$ & All listed buildings \\
BRRM97 & 1997- & $€ 477,815,044$ & All listed buildings \\
BRHB & 1993- & $€ 9,348,555$ & Country estates \\
BRGR & $2001-2006$ & $€ 112,681,651$ & Large listed buildings \\
BRGR02 & 2002 & $€ 18,341,121$ & Large listed buildings \\
BRGR05 & 2006 & $€ 39,708,587$ & Large listed buildings \\
RRWR06 & 2006 & $€ 31,604,492$ & All listed buildings, different sub-programmes \\
RRWR07 & 2007 & $€ 82,146,639$ & All listed buildings, different sub-programmes \\
RRWR08 & 2008 & $€ 27,698,173$ & All listed buildings, different sub-programmes \\
RERRM09 & 2009 & $€ 47,769,035$ & Churches, public buildings, historic infrastructure \\
SRHCE & $2010-2011$ & $€ 18,836,271$ & Churches, mills \\
RM0111 & $2010-2011$ & $€ 45,743,944$ & No residential properties \\
\end{tabular}

Notes: RRWR06 consists of different programmes for residential properties, churches, castles, mills and other listed buildings respectively, each with different subsidy ceilings. RRWR07 has different programmes for large listed buildings, organs, mills, farms and other listed buildings, and RRWR08 focuses on organs, mills, firms and other listed buildings, all with different subsidy ceilings.

were constructed between 1850 and 1940 were mainly listed between 1995 and 2005 . Recently, experts are investigating what buildings of the post-Second World War period are eligible for listing.

We use the listed building dataset and variation in national subsidy programmes to construct the instrument. Table A1 reports the different investment schemes with their total spending. One may immediately observe that the different programmes differ vastly in size, but this is also dependent on the time horizon of the different programmes. These investments schemes are often targeted at specific types of listed buildings. Table A2 describes in more detail what types of listed structures are eligible for each programme. In the first two programmes, the BRRM and BRRM97, all listed buildings were eligible. The BRHB is a relatively small investment scheme particularly for castles and country estates. The BRGR, BRGR02 and BRGR05 programmes were mainly targeted at large investments in (larger) listed structures. We do not have information on the size of listed structures, but some listing categories refer to parts of listed buildings. These categories are unlikely to receive large investments (see Table A2). The RRWR06, RRWR07 and RRWR08 programmes were in principle targeted at all listed buildings. However, RRWR06 consists of different programmes for residential properties, churches, castles, mills and other listed buildings respectively, each with different subsidy ceilings. RRWR07 has different sub-programmes for large listed buildings, organs, mills, farms and other listed buildings, and RRWR08 focuses on organs, mills, firms and other listed buildings, all with different subsidy ceilings. For example, 
TABLE A2 - ELIGIBILITY OF LISTED BUILDING TYPES FOR DIFFERENT SUBSIDY PROGRAMMES

\begin{tabular}{|c|c|c|c|c|c|c|c|c|c|c|c|c|c|c|c|c|c|c|c|c|c|c|c|}
\hline & 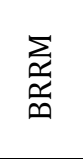 & 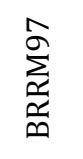 & 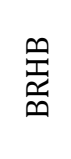 & $\begin{array}{l}\text { 怘 } \\
\text { 品 }\end{array}$ & 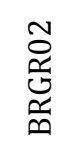 & 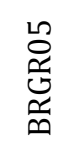 & & & 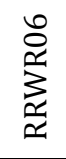 & & & & & 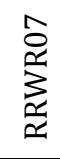 & & & & & & & 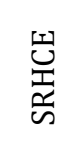 & 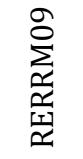 & $\underset{\sum_{1}}{\stackrel{-}{二}}$ \\
\hline & & & & & & & 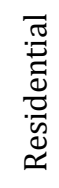 & 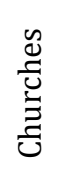 & $\underset{\mathscr{E}}{\stackrel{\mathscr{E}}{\tilde{y}}}$ & $\stackrel{n}{\Sigma}$ & $\frac{\grave{\Phi}}{\dot{D}}$ & 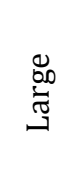 & 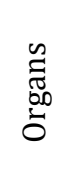 & $\stackrel{\infty}{\Xi}$ & 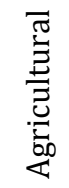 & $\frac{\grave{\Phi}}{5}$ & $\begin{array}{l}\tilde{y} \\
\tilde{\pi} \\
\infty \\
0 \\
0\end{array}$ & $\stackrel{n}{\Xi}$ & 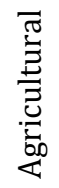 & $\frac{\dot{\Phi}}{\Phi}$ & & & \\
\hline$\%$ of budget & 100 & 100 & 100 & 100 & 100 & 100 & 12 & 46 & 21 & 9 & 12 & 43 & 5 & 11 & 7 & 34 & 8 & 20 & 12 & 60 & 100 & 100 & 100 \\
\hline Buildings, properties & 1 & 1 & 0 & 1 & 1 & 1 & 1 & 0 & 0 & 0 & 0 & 1 & 0 & 0 & 0 & 1 & 0 & 0 & 0 & 1 & 0 & 1 & 1 \\
\hline Parts of buildings & 1 & 1 & 0 & 0 & 0 & 0 & 1 & 0 & 0 & 0 & 0 & 0 & 0 & 0 & 0 & 1 & 0 & 0 & 0 & 1 & 0 & 1 & 0 \\
\hline Religious buildings & 1 & 1 & 0 & 1 & 1 & 1 & 0 & 1 & 0 & 0 & 0 & 1 & 0 & 0 & 0 & 1 & 0 & 0 & 0 & 1 & 1 & 1 & 1 \\
\hline Parts of religious buildings & 1 & 1 & 0 & 0 & 0 & 0 & 0 & 1 & 0 & 0 & 0 & 0 & 1 & 0 & 0 & 0 & 1 & 0 & 0 & 0 & 0 & 1 & 1 \\
\hline Other objects & 1 & 1 & 0 & 1 & 1 & 1 & 0 & 0 & 0 & 0 & 1 & 1 & 0 & 0 & 0 & 1 & 0 & 0 & 0 & 1 & 0 & 0 & 0 \\
\hline Charities & 1 & 1 & 0 & 1 & 1 & 1 & 0 & 0 & 0 & 0 & 1 & 1 & 0 & 0 & 0 & 1 & 0 & 0 & 0 & 1 & 1 & 0 & 0 \\
\hline Public buildings & 1 & 1 & 0 & 1 & 1 & 1 & 0 & 0 & 0 & 0 & 1 & 1 & 0 & 0 & 0 & 1 & 0 & 0 & 0 & 1 & 0 & 1 & 1 \\
\hline Mills & 1 & 1 & 0 & 1 & 1 & 1 & 0 & 0 & 0 & 1 & 0 & 1 & 0 & 1 & 0 & 0 & 0 & 1 & 0 & 0 & 1 & 0 & 0 \\
\hline Defences & 1 & 1 & 0 & 1 & 1 & 1 & 0 & 0 & 0 & 0 & 1 & 1 & 0 & 0 & 0 & 1 & 0 & 0 & 0 & 1 & 0 & 0 & 1 \\
\hline Infrastructure & 1 & 1 & 0 & 1 & 1 & 1 & 0 & 0 & 0 & 0 & 1 & 1 & 0 & 0 & 0 & 1 & 0 & 0 & 0 & 1 & 0 & 1 & 1 \\
\hline Agricultural buildings & 1 & 1 & 0 & 1 & 1 & 1 & 0 & 0 & 0 & 0 & 1 & 1 & 0 & 0 & 1 & 0 & 0 & 0 & 1 & 0 & 0 & 0 & 0 \\
\hline Hotels, restaurants and cafes & 1 & 1 & 0 & 1 & 1 & 1 & 0 & 0 & 0 & 0 & 1 & 1 & 0 & 0 & 0 & 1 & 0 & 0 & 0 & 1 & 0 & 0 & 0 \\
\hline Castles and country estates & 1 & 1 & 1 & 1 & 1 & 1 & 0 & 0 & 1 & 0 & 0 & 1 & 0 & 0 & 0 & 1 & 0 & 0 & 0 & 1 & 0 & 0 & 1 \\
\hline
\end{tabular}


almost 50 percent of the RRWR06 budget is spent on religious buildings, while the RRWR07 has spent more than 10 percent of the budget on mills. The RERRM09, SRHCE and RM0111 are relatively small investment programmes that target specific listed buildings.

We use this information to construct the instrument. We first assume that only structures that are listed in 1985 were eligible for the entire study period. To construct the instrument we use in the empirical analysis, we assume that each listed building is eligible for every programme. We then compute the predicted subsidy for each listed building in each year for each programme by dividing the total budget spent by the programme by the number of listed buildings that are eligible. The predicted subsidy for each listed building in each year is then determined by simply adding up the predicted subsidies for all programmes. Because we do not have information on the size of listed buildings, the expected subsidy for each listed building in each year is independent of the size. This may arguably lead to some measurement error in the instrument (because larger listed buildings are more likely to receive subsidies). We define the expected subsidy per area by aggregating the expected subsidies per listed building in each year at the neighbourhood level. In the sensitivity analysis, we also construct an instrument that takes into account that each listed structuremay not be eligible for each programme (based on its type, see Table A2).

\section{A.2 Investments in the exterior and interior of listed buildings}

We are interested in the external effect of investments in cultural heritage. We therefore focus on investments that have made changes to the exterior of the building. Often, we do not know what specific part of the building is renovated. Moreover, many investments apply to both the exterior and the interior of the listed building. However, for a reasonable number of investments, we are sure that the investments only apply to the interior, based on the description of the investment. The investments have been excluded when the following description applies: aardappelkelder, achterhuis, annunciatie, aswiel molen, attic, balklagen, behangsel van Jacob Cats, beschoeiing, blaasbalg, bliksemafleider, bouwhistorisch onderzoek, bouwhistorisch onderzoek, brandbeveiliging, consistorie, epitafen, gebinten, gedenkborden, gerfkamer, gewelven, gobelins, graftombe Floris V, graftombe in kerk, grafzerken, haardpartij, hoofdaltaar, kapvoetconstructie, kerkankers, kerkklok, knaagkeverbestrijding, ladderhaken, magazijn, maquette, molenstuw, muurfragment, muurplaatankers, muurschilderingen, natte muren, natuurparken in Terschelling, onderzoek, orgel balkon, orgel luiken, orgels, plafond, plankosten, plankosten, plebanie, podium concertgebouw, preekstoel, spantbenen, stijlkamers, stoelen, trapopgang, urinoir, ventilatie, vieringgewelf, vijzel, vloerverwarming, voorbereidingskosten, waterpasmeting.

\section{A.3 Historic districts and runner-up locations}

Figure displays the designated historic districts ( $1^{\text {st }}$ generation), the designated MSPdistricts (2nd generation) and the runner-up MSP-districts, which are areas that eventually 


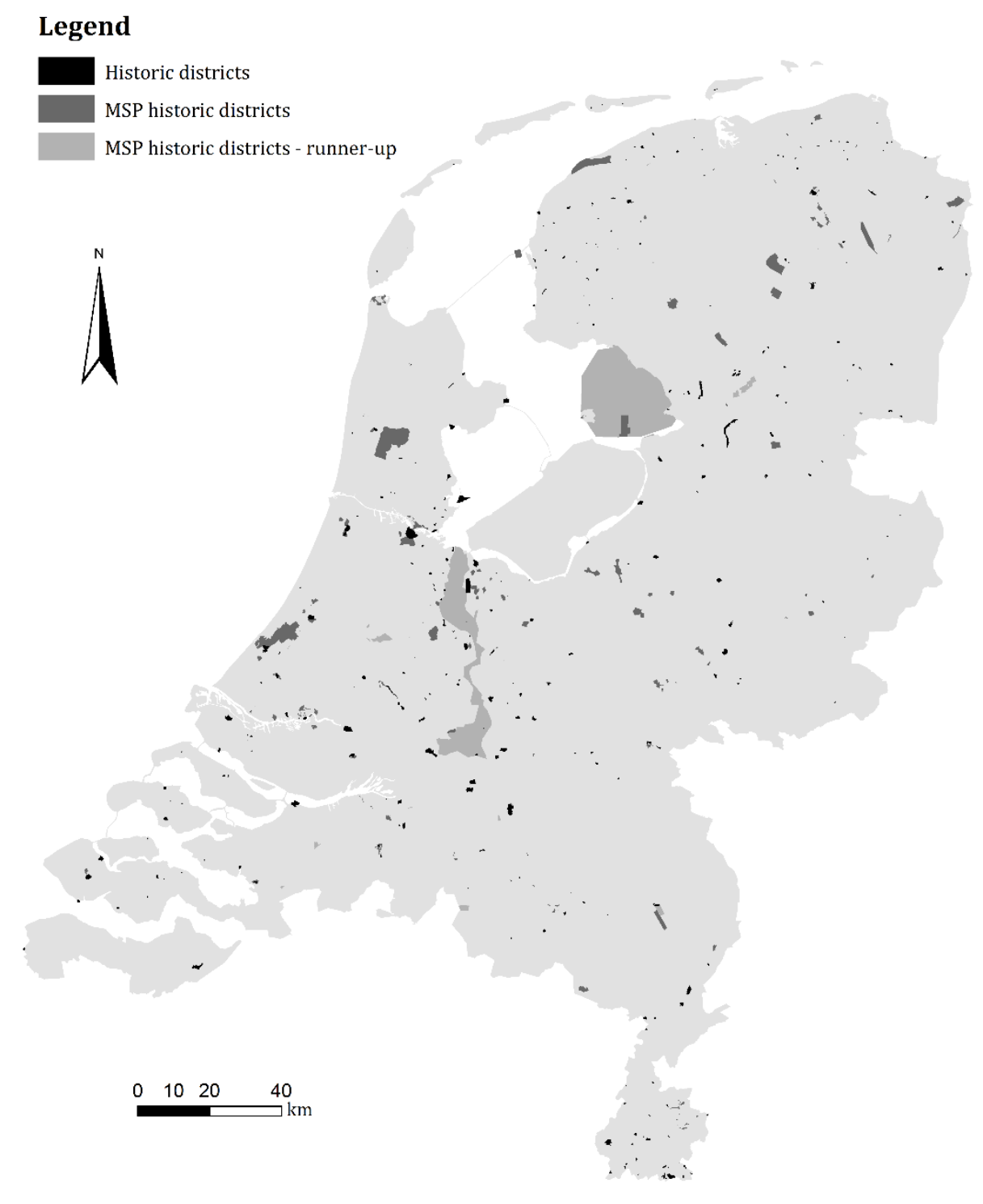

FIGURE A1 — HISTORIC DISTRICTS, MSP-DISTRICTS AND RUNNER-UP MSP-DISTRICTS

were not designated as historic district. One may observe that there are some two large MSP runner-up historic districts in mostly rural areas. We therefore also estimate a specification where we only focus on designated MSP-districts, to account for the fact that runner-up MSPdistricts may have different unobserved trends than designated MSP-districts (see column (6), Table 6). 


\section{Appendix B. Other results}

\section{B.1 Descriptive statistics for changes}

Table B1 reports the yearly changes for the repeat sales sample (so we divide the difference by the number of years between the two transactions). The average change in house price is about $€ 10,000$ per year. The average investments in neighbourhoods are about $€ 7,000$ per year per square kilometre. Differences in house sizes are always lower than 20 square meter, because observations are otherwise excluded from the analysis.

TABLE B1 — DESCRIPTIVE STATISTICS FOR YEARLY CHANGES, REPEAT-SALES SAMPLE

\begin{tabular}{|c|c|c|c|c|}
\hline & \multicolumn{4}{|c|}{ Full sample } \\
\hline & Mean & Std.dev. & Min & Max \\
\hline$\Delta$ Price per $\mathrm{m}^{2}$ & 9,651 & 11,099 & $-331,033$ & 432,879 \\
\hline$\Delta$ Investments $\left(\right.$ in $€$ per $\left.\mathrm{km}^{2}\right)$ & 6,879 & 45,797 & 0 & $1,947,793$ \\
\hline$\Delta$ Subsidies $\left(\right.$ in $€$ per $\mathrm{km}^{2}$ ) & 2,583 & 19,777 & 0 & $1,213,507$ \\
\hline$\Delta$ Targeted buildings $\left(\right.$ per $\mathrm{km}^{2}$ ) & 0.0366 & 0.4434 & 0.0000 & 88.8469 \\
\hline$\Delta$ Predicted investments (in million $€$ per & & & & \\
\hline $\begin{array}{l}\left.k m^{2}\right) \\
\Delta \text { Size }\left(\text { in } m^{2}\right)\end{array}$ & $\begin{array}{l}0.0041 \\
0.0698\end{array}$ & $\begin{array}{l}0.0397 \\
1.9095\end{array}$ & $\begin{array}{r}0.0000 \\
-19.0000\end{array}$ & $\begin{array}{r}3.1501 \\
19.0000\end{array}$ \\
\hline$\Delta$ Rooms & 0.0000 & 0.0000 & -9.0000 & 9.0000 \\
\hline$\Delta$ Central heating & 0.0113 & 0.0932 & -1.0000 & 1.0000 \\
\hline$\Delta$ Maintenance quality - inside & 0.0250 & 0.0956 & -0.7500 & 1.0000 \\
\hline$\Delta$ Maintenance quality - outside & 0.0080 & 0.0724 & -0.7500 & 1.0000 \\
\hline$\Delta$ Maintenance quality - missing & 0.0180 & 0.1919 & -1.0000 & 1.0000 \\
\hline
\end{tabular}

Notes: The number of observations is 325,533 and for the corrected maintenance score it is 40,053

TABLE B2 - FIRST-STAGE RESULTS (FOR HOUSE PRICES)

Dependent variable: $\Delta$ Investments

\begin{tabular}{|c|c|c|c|c|}
\hline & (3) & $(4)$ & (5) & $(6)$ \\
\hline$\Delta$ Predicted investments (in million $€$ per $\mathrm{km}^{2}$ ) & $\begin{array}{l}0.384^{* * *} \\
(0.0865)\end{array}$ & $\begin{array}{l}0.350^{* * *} \\
(0.0704)\end{array}$ & $\begin{array}{l}0.516^{* * *} \\
(0.0703)\end{array}$ & $\begin{array}{l}0.243^{* * *} \\
(0.0393)\end{array}$ \\
\hline$\Delta$ House size $(\log )$ & $\begin{array}{l}-0.00299 \\
(0.00725)\end{array}$ & $\begin{array}{l}-0.00127 \\
(0.00569)\end{array}$ & $\begin{array}{c}-0.00212 \\
(0.00481)\end{array}$ & $\begin{array}{c}0.000150 \\
(0.00545)\end{array}$ \\
\hline$\Delta$ Rooms & $\begin{array}{c}-0.00190^{* * *} \\
(0.000691)\end{array}$ & $\begin{array}{c}-0.00135^{* * *} \\
(0.000519)\end{array}$ & $\begin{array}{l}-0.00107^{* *} \\
(0.000427)\end{array}$ & $\begin{array}{l}-0.000634^{*} \\
(0.000341)\end{array}$ \\
\hline$\Delta$ Central heating & $\begin{array}{l}0.0117^{* * *} \\
(0.00399)\end{array}$ & $\begin{array}{c}0.00201 \\
(0.00151)\end{array}$ & $\begin{array}{c}0.00173 \\
(0.00147)\end{array}$ & $\begin{array}{c}0.000464 \\
(0.00130)\end{array}$ \\
\hline$\Delta$ Maintenance level - inside & $\begin{array}{c}0.00396 \\
(0.00414)\end{array}$ & $\begin{array}{c}0.00222 \\
(0.00250)\end{array}$ & $\begin{array}{c}0.00334 \\
(0.00217)\end{array}$ & $\begin{array}{c}-0.000393 \\
(0.00234)\end{array}$ \\
\hline$\Delta$ Maintenance level - outside & $\begin{array}{l}-0.00327 \\
(0.00490)\end{array}$ & $\begin{array}{c}-0.00369 \\
(0.00302)\end{array}$ & $\begin{array}{c}-0.00349 \\
(0.00295)\end{array}$ & $\begin{array}{c}-0.00194 \\
(0.00286)\end{array}$ \\
\hline$\Delta$ Year fixed effects (27) & Yes & Yes & Yes & Yes \\
\hline Neighbourhood fixed effects $(7,080)$ & No & Yes & Yes & Yes \\
\hline Trend of number listed buildings, $\Upsilon(\cdot)$ & No & No & Yes & Yes \\
\hline Number of observations & 360,602 & 360,602 & 360,602 & 144,152 \\
\hline$R^{2}$ & 0.147 & 0.537 & 0.565 & 0.617 \\
\hline First-stage $F$-statistic & 19.73 & 25.33 & 55.29 & 40.22 \\
\hline
\end{tabular}


TABLE B3 - FiRST-STAGE RESUlTS (FOR MAINTENANCE STATE)

Dependent variable: $\Delta$ Investments

\begin{tabular}{|c|c|c|c|c|}
\hline & (3) & (4) & $(5)$ & (6) \\
\hline$\Delta$ Predicted investments (in million $€$ per $\mathrm{km}^{2}$ ) & $\begin{array}{l}0.449^{* * *} \\
(0.0625)\end{array}$ & $\begin{array}{l}0.422^{* * *} \\
(0.0336)\end{array}$ & $\begin{array}{l}0.609^{* * *} \\
(0.0331)\end{array}$ & $\begin{array}{l}0.308^{* * *} \\
(0.0808)\end{array}$ \\
\hline$\Delta$ House size $(\log )$ & $\begin{array}{l}-0.0227 \\
(0.0269)\end{array}$ & $\begin{array}{r}-0.00722 \\
(0.0195)\end{array}$ & $\begin{array}{l}-0.00351 \\
(0.0193)\end{array}$ & $\begin{array}{l}-0.00658 \\
(0.0239)\end{array}$ \\
\hline$\Delta$ Rooms & $\begin{array}{c}0.00108 \\
(0.00152)\end{array}$ & $\begin{array}{l}0.000686 \\
(0.00152)\end{array}$ & $\begin{array}{c}0.00125 \\
(0.00152)\end{array}$ & $\begin{array}{c}0.00103 \\
(0.00144)\end{array}$ \\
\hline$\Delta$ Year fixed effects (27) & Yes & Yes & Yes & Yes \\
\hline Neighbourhood fixed effects $(7,080)$ & No & Yes & Yes & Yes \\
\hline Trend of number listed buildings, $\Upsilon(\cdot)$ & No & No & Yes & Yes \\
\hline $\begin{array}{l}\text { Number of observations } \\
R^{2} \\
\text { First-stage } F \text {-statistic }\end{array}$ & $\begin{array}{l}42,728 \\
0.165 \\
51.77\end{array}$ & $\begin{array}{c}42,728 \\
0.544 \\
181.1\end{array}$ & $\begin{array}{c}42,728 \\
0.583 \\
389\end{array}$ & $\begin{array}{l}17,326 \\
0.593 \\
19.09\end{array}$ \\
\hline
\end{tabular}

\section{B.2 First-stage results}

Table B2 reports first-stage regression results, where the column numbers refer to the corresponding specifications in Table 2. It is shown that predicted investments are a strong predictor of actual investments, as the first-stage $F$-statistic is well above the rule-of-thumb value of 10 . The coefficient is lower than one, because we exclude locations that have received large subsidies, so the expected value for the other area is than less than the total investments in cultural heritage divided by the total number of listed buildings. Table B3 reports results for the state of maintenance, where we have fewer observations. The coefficients are then similar, although the first-stage $F$-statistics tend to be higher.

\section{B.3 Average maintenance level in the neighbourhood}

Our theoretical framework predicts that the change in prices due to investments in cultural heritage is a function of changes in the quality of nearby listed buildings and the quality of other properties (see equation (5)). Although we do not find that the maintenance level is affected by investments in cultural heritage, it might be that our dataset is too small to detect the change in the maintenance level of properties. To test whether the conclusion that price effects of investments in cultural heritage are mainly caused by a direct improvement of listed buildings, we may also directly control for the average maintenance level in the neighbourhood.

Of course, we do not observe the maintenance level of all properties at each moment in time, but we observe only the maintenance level of properties that are sold. We then 
TABLE B4 - BASELINE RESULTS FOR HOUSE PRICES, INCLUDING THE AVERAGE MAINTENANCE LEVEL IN THE NEIGHBOURHOOD Dependent variable: $\Delta$ price $(\log )$

\begin{tabular}{|c|c|c|c|c|c|c|}
\hline & $(1)$ & (2) & (3) & (4) & (5) & (6) \\
\hline & OLS & OLS & 2SLS & 2SLS & 2SLS & 2SLS \\
\hline$\Delta$ Investments (in million $€$ per $\mathrm{km}^{2}$ ) & $\begin{array}{l}0.0162^{* * *} \\
(0.00556)\end{array}$ & $\begin{array}{l}0.0146^{* * *} \\
(0.00512)\end{array}$ & $\begin{array}{l}0.0318^{* * *} \\
(0.00894)\end{array}$ & $\begin{array}{l}0.0287^{* *} \\
(0.0117)\end{array}$ & $\begin{array}{c}0.0154^{* *} \\
(0.00713)\end{array}$ & $\begin{array}{l}0.0531^{* * *} \\
(0.0109)\end{array}$ \\
\hline $\begin{array}{l}\Delta \text { Average maintenance level in } \\
\text { neighbourhood (adjusted) }\end{array}$ & $\begin{array}{l}-0.0102^{* *} \\
(0.00508)\end{array}$ & $\begin{array}{l}-0.00202 \\
(0.00485)\end{array}$ & $\begin{array}{l}-0.00186 \\
(0.00485)\end{array}$ & $\begin{array}{l}0.000244 \\
(0.00412)\end{array}$ & $\begin{array}{l}0.000106 \\
(0.00412)\end{array}$ & $\begin{array}{c}-0.00394 \\
(0.00504)\end{array}$ \\
\hline $\begin{array}{l}\Delta \text { Average maintenance level in } \\
\text { neighbourhood (all properties) }\end{array}$ & $\begin{array}{l}0.382^{* * *} \\
(0.0163)\end{array}$ & $\begin{array}{l}0.153^{* * *} \\
(0.0148)\end{array}$ & $\begin{array}{l}0.151^{* * *} \\
(0.0149)\end{array}$ & $\begin{array}{c}0.0600^{* * *} \\
(0.0127)\end{array}$ & $\begin{array}{c}0.0610^{* * *} \\
(0.0127)\end{array}$ & $\begin{array}{c}0.0270 \\
(0.0169)\end{array}$ \\
\hline$\Delta$ Control variables (6) & No & Yes & Yes & Yes & Yes & Yes \\
\hline$\Delta$ Year fixed effects (27) & Yes & Yes & Yes & Yes & Yes & Yes \\
\hline Neighbourhood fixed effects $(7,080)$ & No & No & No & Yes & Yes & Yes \\
\hline Trend of listed building density, $\Upsilon(\cdot)$ & No & No & No & No & Yes & Yes \\
\hline $\begin{array}{l}\text { Number of observations } \\
R^{2}\end{array}$ & $\begin{array}{c}360,602 \\
0.814\end{array}$ & $\begin{array}{c}360,602 \\
0.842\end{array}$ & 360,602 & 360,602 & 360,602 & 144,152 \\
\hline First-stage $F$-statistic & & & 20.04 & 25.33 & 57.08 & 39.72 \\
\hline
\end{tabular}

determine the average maintenance level of properties that are sold in a neighbourhood in a specific year. If there are no sales in a specific year in a neighbourhood we take the value of the preceding year. One variable only includes the maintenance rate if the inside or outside maintenance level deviates from 0.75 , which also may indicate a missing value. The other variable includes all properties and ignores any potential measurement error. Table B4 reports the results.

Column (1) is the naïve specification without housing attributes, but with the average maintenance level in the neighbourhood. It is shown that the effect is similar to the baseline specification. This also holds if we include housing attributes in column (2), use the predicted investments as an instrument in column (3), add neighbourhood fixed effects in column (4), include a trend of listed building density in column (5), and only focus on transactions that take place after 2000 in column (6). The coefficients is only a little lower in all specifications, which makes it unlikely that the indirect effect of investments in cultural heritage via an improved level of the outward appearance of houses in the neighbourhood is important. The average maintenance level in the neighbourhood seems to have a positive effect, at least when we include the maintenance level of all properties in the neighbourhood, but once we better control for unobserved trends, the effect becomes smaller and statistically insignificant when we only focus on properties that are sold after 2000. 


\section{B.4 A fixed effects approach}

The baseline results are based on a repeat sales approach. Instead, we may also include postcode fixed effects. In the Netherlands, postcode areas encompass about half a street (on average 15 households). The fixed effects deal essentially with all unobserved time-invariant spatial attributes. We then estimate the following regression equation:

$$
y_{\text {int }}=\alpha z_{n t}+\beta x_{i t}+\theta_{t}+\xi_{i}+\epsilon_{\text {int }},
$$

where $y_{\text {int }}$ is the log price of a house, $x_{i t}$ are housing attributes, including the construction year, house type, and $\xi_{i}$ are postcode fixed effects. In Table B5 we report the results.

In column (1) we regress the house price on investments, postcode fixed effects and year fixed effects. The coefficient implies that a million euro increase in investments per square kilometre increases house prices by 1.26 percent. This effect is slightly higher when we control for 19 housing attributes. In column (3) we instrument the investments using the predicted investments (see equation (9)). The price effect is then very similar. When we only focus on properties transacted after 2000, the price increase due to a million euro increase in investments per square kilometre is 2.55 percent. When we only focus on areas that had a positive number of listed buildings in 1985, the coefficient is almost identical, despite the fact that the number of observations reduce with almost 70 percent. Hence, the fixed effects models seem to confirm a price effect in the same order of magnitude compared to the repeat sales models.

TABLE B5 - POSTCODE FIXED EFFECTS MODELS FOR HOUSE PRICE Dependent variable: price (log)

\begin{tabular}{|c|c|c|c|c|c|}
\hline & (1) & (2) & (3) & (4) & (5) \\
\hline & OLS & OLS & 2SLS & 2SLS & 2SLS \\
\hline Investments (in million $€$ per $\mathrm{km}^{2}$ ) & $\begin{array}{l}0.0126^{* * *} \\
(0.00475)\end{array}$ & $\begin{array}{l}0.0155^{* * *} \\
(0.00441)\end{array}$ & $\begin{array}{c}0.0180^{* *} \\
(0.00808)\end{array}$ & $\begin{array}{l}0.0255^{* * *} \\
(0.00800)\end{array}$ & $\begin{array}{l}0.0253^{* * *} \\
(0.00859)\end{array}$ \\
\hline Year fixed effects (27) & Yes & Yes & Yes & Yes & Yes \\
\hline Postcode fixed effects $(152,949)$ & Yes & Yes & Yes & Yes & Yes \\
\hline Housing attributes (19) & No & Yes & Yes & Yes & Yes \\
\hline $\begin{array}{l}\text { Number of observations } \\
R^{2}\end{array}$ & $\begin{array}{c}2,104,343 \\
0.826\end{array}$ & $\begin{array}{c}2,104,343 \\
0.932\end{array}$ & $2,104,343$ & $1,339,043$ & 434,538 \\
\hline First-stage $F$-statistic & & & 36.52 & 20.96 & 27.27 \\
\hline
\end{tabular}


TABLE B6 - SENSITIVITY ANALYSIS: LARGE INVESTMENTS

Dependent variable: $\Delta$ price $(\log )$

\begin{tabular}{|c|c|c|c|}
\hline & (1) & (2) & (3) \\
\hline & $2 \times$ outlier value & $1 / 2 \times$ outlier value & Targeted objects \\
\hline & 2SLS & 2SLS & 2SLS \\
\hline$\Delta$ Investments (in million $€$ per $\mathrm{km}^{2}$ ) & $\begin{array}{l}0.0174^{* * *} \\
(0.00532)\end{array}$ & $\begin{array}{l}0.0531^{* *} \\
(0.0228)\end{array}$ & \\
\hline$\Delta$ Targeted buildings (per $\mathrm{km}^{2}$ ) & & & $\begin{array}{l}0.00120^{* * *} \\
(0.000391)\end{array}$ \\
\hline$\Delta$ Control variables (6) & Yes & Yes & Yes \\
\hline$\Delta$ Year fixed effects (27) & Yes & Yes & Yes \\
\hline Neighbourhood fixed effects $(7,080)$ & Yes & Yes & Yes \\
\hline Trend of listed building density, $\Upsilon(\cdot)$ & Yes & Yes & Yes \\
\hline Number of observations & 366,667 & 350,638 & 378,877 \\
\hline First-stage $F$-statistic & 24.97 & 45.47 & 20.18 \\
\hline
\end{tabular}

\section{B.5 Large investments}

Investments are strongly skewed, with some areas receiving substantial investments in cultural heritage (see e.g. Van Duijn et al., 2012). Until now, we have excluded the upper 2.5 percent of the neighbourhoods that have received more than $€ 2$ million investment per square kilometre in one year once during the study period. In Table B6 we investigate whether this is choice is important for our results.

Column (1), Table B6, we exclude neighbourhoods that have received more than $€ 4$ million investment per square kilometre in one year once during the study period, which is twice the base value. The results indicate that the effect is very similar to the baseline results. Column (2) excludes observations in neighbourhoods that have received more than $€ 1$ million investment per square kilometre in one year once during the study period, so half the base value. The coefficient becomes then somewhat larger in magnitude, although it is not statistically significantly different from the initial baseline estimate. Column (3), Table B6, does not use investments in euros, but investigates the impact of the density of targeted objects, so that we can include all observations. The number of targeted buildings is much less skewed than the absolute value of investments, so the likelihood that our results are driven by some large investments is then much lower. The results suggests that a standard deviation increase in the number of targeted buildings leads to an increase in the house price of 1.46 percent, confirming the importance of investments in cultural heritage. ${ }^{23}$

${ }^{23}$ Note that the standard deviation of the number of targeted buildings is 12.146 in the full sample, which is about 3.5 times the standard deviation for the sample where we exclude neighbourhoods that have received more than $€ 2$ million investment per square kilometre in one year once during the study period (see Table 1). 